\title{
Radiopharmaceuticals in Preclinical and Clinical Development for Monitoring of Therapy with PET
}

\author{
Mark P.S. Dunphy ${ }^{1}$ and Jason S. Lewis ${ }^{1,2}$ \\ ${ }^{1}$ Department of Radiology, Memorial Sloan-Kettering Cancer Center, New York, New York; and ${ }^{2}$ Molecular Pharmacology and \\ Chemistry, Sloan-Kettering Institute for Cancer Research, New York, New York
}

\begin{abstract}
This review article discusses PET agents, other than ${ }^{18} \mathrm{~F}-\mathrm{FDG}$, with the potential to monitor the response to therapy before, during, or after therapeutic intervention. This review deals primarily with non-18F-FDG PET tracers that are in the final stages of preclinical development or in the early stages of clinical application for monitoring the therapeutic response. Four sections related to the nature of the tracers are included: radiotracers of DNA synthesis, such as the 2 most promising agents, the thymidine analogs $3^{\prime}-{ }^{18} \mathrm{~F}$-fluoro-3'-deoxythymidine and ${ }^{18} \mathrm{~F}-1-\left(2^{\prime}\right.$-deoxy2 '-fluoro- $\beta$-D-arabinofuranosyl)thymine; agents for PET imaging of hypoxia within tumors, such as ${ }^{60 / 62 / 64} \mathrm{Cu}$-labeled diacetylbis $\left(N^{4}\right.$-methylthiosemicarbazone) and ${ }^{18} \mathrm{~F}$-fluoromisonidazole; amino acids for PET imaging, including the most popular such agent, L-[methyl- $\left.{ }^{11} \mathrm{C}\right]$ methionine; and agents for the imaging of tumor expression of androgen and estrogen receptors, such as $16 \beta-{ }^{18} \mathrm{~F}$-fluoro- $5 \alpha$-dihydrotestosterone and $16 \alpha-{ }^{18} \mathrm{~F}$-fluoro$17 \beta$-estradiol, respectively.
\end{abstract}

Key Words: PET; therapy monitoring; hypoxia; steroid receptors; proliferation

J Nucl Med 2009; 50:106S-121S

DOI: 10.2967/jnumed.108.057281

\section{T} his special issue of The Journal of Nuclear Medicine is aimed at exploring the clinical impact of PET in individualizing treatment regimens in cancer patients and describing the potential use of PET in personalized medicine. However, it is clear that although ${ }^{18} \mathrm{~F}-\mathrm{FDG}$ is the mainstay for PET, it is not suited for all applications and, in particular, for monitoring the effectiveness of highly specialized therapies. This review article contains 4 sections related to the biologic targets of tracers: radiotracers of DNA synthesis, agents for PET imaging of hypoxia, amino acids for PET imaging, and agents for the imaging of androgen and estrogen receptors (ERs). The biology of the systems and the clinical trials (if applicable) that have been undertaken are the main topics covered. The results of the trials discussed are summarized in

Received Oct. 31, 2008; revision accepted Feb. 16, 2009.

For correspondence or reprints contact: Jason S. Lewis, Department of Radiology, Memorial Sloan-Kettering Cancer Center, 1275 York Ave., New York, New York 10065

E-mail: lewisj2@mskcc.org

COPYRIGHT () 2009 by the Society of Nuclear Medicine, Inc. tabular format (Table 1). This review is extensive but not exhaustive, and focus was placed on the radiopharmaceuticals that are considered to be the most widely studied in each category. Given the breadth of cancer biology and the targets to be explored, the future prospects for monitoring therapy with novel PET agents that are currently in preclinical development are discussed.

It is important not to overlook SPECT radiopharmaceuticals for the prediction and detection of tumor responses for several diseases and therapeutic regimens. Some are already in common use; examples of such agents are radioiodide for thyroid cancer (1-3); radiolabeled metaiodobenzylguanidine (4-11) and radiolabeled octreotide analogs $(12,13)$ for neuroendocrine tumors; and the anti-CD20 radioantibodies ibritumomab tiuxetan (Zevalin; Cell Therapeutics, Inc.) and tositumomab (Bexxar; GlaxoSmithKline), which have been approved by the U.S. Food and Drug Administration for use in lymphoma. Others, such as radiolabeled annexin molecules for the detection of cell apoptosis, have shown great promise in clinical trials $(14,15)$. However, these SPECT tracers are not the focus of this review of PET agents.

\section{IMAGING MARKERS OF DNA SYNTHESIS}

Clinical trials of radiotracers of DNA synthesis for tumor imaging have identified the thymidine analogs $3^{\prime}{ }_{-}{ }^{18} \mathrm{~F}$-fluoro$3^{\prime}$-deoxythymidine $\left({ }^{18} \mathrm{~F}-\mathrm{FLT}\right)($ Fig. $1 \mathrm{~A})$ and ${ }^{18} \mathrm{~F}-1$ - $\left(2^{\prime}\right.$-deoxy$2^{\prime}$-fluoro- $\beta$-D-arabinofuranosyl)thymine $\left({ }^{18} \mathrm{~F}-\mathrm{FMAU}\right)$ (Fig. $1 \mathrm{~B})$ as the 2 most promising agents. Bading and Shields recently provided an excellent, concise overview of these 2 tracers (and others) in clinical assays of cellular proliferation (16). Our review focuses in detail on the use of ${ }^{18} \mathrm{~F}-\mathrm{FLT}$ and ${ }^{18} \mathrm{~F}-\mathrm{FMAU}$ for the prediction and detection of responses to various anticancer regimens and on the published results of clinical trials.

What Does ${ }^{18} \mathrm{~F}-\mathrm{FLT}$ and ${ }^{18} \mathrm{~F}$-FMAU Uptake Signify?

Insight into the pharmacokinetics of ${ }^{18} \mathrm{~F}-\mathrm{FLT}$ and ${ }^{18} \mathrm{~F}$ FMAU should assist in the interpretation of imaging for the purpose of monitoring the clinical response to a therapeutic regimen. During the 2- to 3-h time period after intravenous injection, when PET with ${ }^{18} \mathrm{~F}$-FLT or ${ }^{18} \mathrm{~F}$-FMAU usually is 


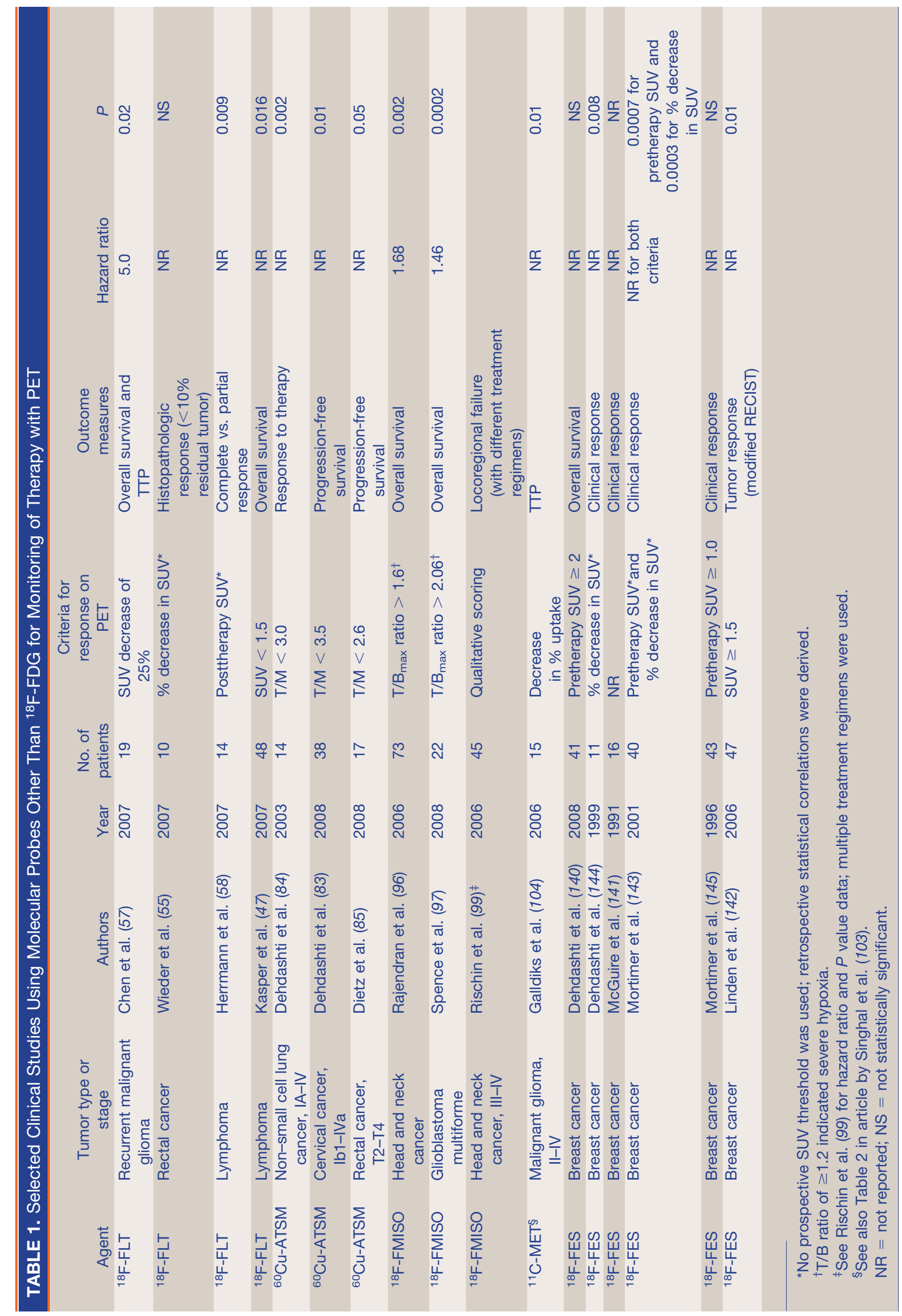




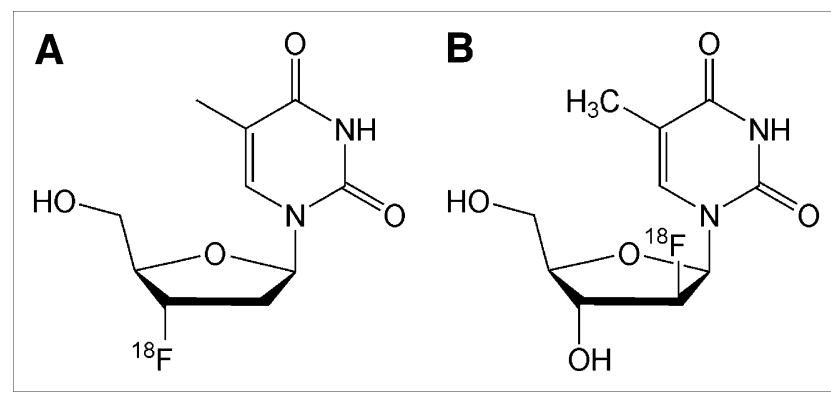

FIGURE 1. (A) ${ }^{18} \mathrm{~F}-\mathrm{FLT}$. (B) ${ }^{18} \mathrm{~F}-\mathrm{FMAU}$.

performed, the activity of thymidine kinase (TK), a key enzyme in the salvage pathway of DNA synthesis, affects the cellular retention (or trapping) of these tracers. The phosphorylation of thymidine and its analogs makes these exogenous molecules too polar to exit the cell via the plasma membrane. DNA synthesis occurs in both the cytosol and the mitochondria. Different isoenzymes of TK trap thymidine and its analogs in the cytosol and mitochondria: TK 1 (TK1) and TK 2 (TK2), respectively. Cytosolic TK1 favors ${ }^{18} \mathrm{~F}-\mathrm{FLT}$ over ${ }^{18} \mathrm{~F}-\mathrm{FMAU}$ as a substrate (17); mitochondrial TK2 favors ${ }^{18} \mathrm{~F}-\mathrm{FMAU}$ (18). The TK1 and TK2 selectivities of ${ }^{18} \mathrm{~F}$-FLT and ${ }^{18} \mathrm{~F}$-FMAU are manifested in the normal biodistributions of these tracers. For example, human cardiomyocytes are rich in mitochondrial TK2; visualization of the human heart is distinct on ${ }^{18} \mathrm{~F}$-FMAU PET images but faint on ${ }^{18} \mathrm{~F}$-FLT PET images.

Cytosolic TK1 activity is dependent on the cell cycle, but mitochondrial TK2 activity is not (18). Mitochondrial TK2 expression is independent of the cell cycle, whereas cytosolic TK1 expression is high during the $S, G_{2}$, and $M$ phases and low during the $\mathrm{G}_{0}$ and $\mathrm{G}_{1}$ phases. Hence, ${ }^{18} \mathrm{~F}$ FMAU PET visualizes the activity of TK2 in the mitochondrial DNA synthesis pathway, but tissue concentrations of ${ }^{18} \mathrm{~F}$-FMAU do not seem to be an accurate index of cellular proliferation (19). Bone marrow, for example, a proliferative tissue containing an abundance of cells progressing through the cell cycle, avidly accumulates ${ }^{18} \mathrm{~F}$-FLT but not ${ }^{18} \mathrm{~F}-$ FMAU. TK1 expression, but not TK2 expression, has been associated with aggressive disease in breast cancer $(20,21)$. However, ${ }^{18} \mathrm{~F}-\mathrm{FMAU}$ uptake seems to be an accurate index of the total mass of mitochondria in a tissue. Besides the ${ }^{18} \mathrm{~F}-\mathrm{FMAU}$ avidity of mitochondrion-rich cardiomyocytes, conditions that induce an increase in cardiomyondrial mass in cancer cells will increase the cellular accumulation of ${ }^{18}$ F-FMAU (18).

\section{Do Changes in ${ }^{18}$ F-FLT and ${ }^{18}$ F-FMAU Uptake Signify} Mere Biologic Effects or Therapeutic Efficacy?

Basically, then, ${ }^{18} \mathrm{~F}-\mathrm{FLT}$ PET provides data on TK1 activity and an index of cell cycling and tissue proliferation, and ${ }^{18} \mathrm{~F}$-FMAU PET provides data on TK2 activity and an index of mitochondrial mass in a tissue. Because TK1 and
TK2 are independent enzymes, changes in ${ }^{18} \mathrm{~F}-\mathrm{FLT}$ and ${ }^{18} \mathrm{~F}-$ FMAU uptake appear to provide different types of biologic information (18).

Knowledge of the pharmacodynamics or biomolecular effects of a therapeutic regimen is required for an accurate interpretation of changes in the uptake of ${ }^{18} \mathrm{~F}$-FLT or ${ }^{18} \mathrm{~F}$ FMAU for the purpose of monitoring a clinical response. Although the induction of cell death by cytotoxic regimens may decrease the total amount of tissue TK present, the enzymatic activity of the residual tissue TK may increase or decrease; cytostatic regimens also may increase or decrease TK activity. Hence, the biologic effect of therapy on ${ }^{18} \mathrm{~F}-$ FLT or ${ }^{18} \mathrm{~F}-\mathrm{FMAU}$ uptake and its implication for the response of a tumor to therapy require scientific dissection.

\section{In Vitro and In Vivo Studies}

In vitro, TK1 and TK2 expression increased after a single high-dose-rate irradiation of cancer cells but normalized by $24 \mathrm{~h}$ (22). Several chemotherapeutic agents were reported to decrease the expression of both TK1 and TK2; these included dideoxycytidine (23) and arabinosylcytosine (24). In a xenograft model, the anti-epidermal growth factor receptor (EGFR) agents cetuximab and erlotinib decreased tumor TK1 expression, with a concomitant reduction in ${ }^{18} \mathrm{~F}$-FLT uptake (25). In vitro, ${ }^{18} \mathrm{~F}$-FLT uptake by cancer cells changed markedly in the first $24 \mathrm{~h}$ after therapy. In cells, cytostatic concentrations of cisplatin markedly decreased ${ }^{18} \mathrm{~F}$-FLT uptake $(26,27)$; inhibitory concentrations of 5-fluorouracil (5-FU) (26), methotrexate (26), doxorubicin (28), and gemcitabine (26) increased total ${ }^{18} \mathrm{~F}$-FLT uptake (26) while the growth of cells slowed. In other in vitro studies, some involving tumor spheroid models, there was a decrease in ${ }^{18} \mathrm{~F}$-FLT uptake after treatment with doxorubicin (27,29), docetaxel (27), and an Hsp90 inhibitor (30). In a study in which several tracers and treatments were compared, little to no change in ${ }^{18} \mathrm{~F}$-FLT uptake occurred after treatment of a breast cancer cell line with tamoxifen or imatinib, but this finding correlated with the minimal effect of the treatment on cellular proliferation (27). For 5-FU, a marked increase in ${ }^{18} \mathrm{~F}$-FLT uptake was observed in vivo (31). Others reported that 5-FU increased TK1 levels $\sim 163 \%-180 \%$ at $\leq 4 \mathrm{~h}(28,31)$ and up to $44 \%$ at $72 \mathrm{~h}(28)$ but that total ${ }^{18} \mathrm{~F}-\mathrm{FLT}$ uptake in treated cells (normalized to the uptake in untreated cells) did not change, except at $72 \mathrm{~h}$, when it decreased; this apparent lack of correlation between changes in TK1 levels and ${ }^{18} \mathrm{~F}$ FLT uptake was discordant with the majority of evidence. Hence, the decrease observed at $72 \mathrm{~h}$ but not before might have been attributable, in part, to differences in the sizes of the cell populations.

5-FU inhibits thymidylate synthase, a key enzyme in the de novo DNA synthesis pathway; hence, a shift to the salvage pathway induced by 5-FU blockade of the de novo pathway should increase TK1 levels and ${ }^{18} \mathrm{~F}-\mathrm{FLT}$ uptake. Paclitaxel did not change ${ }^{18}$ F-FLT uptake, although cells accumulated in the $\mathrm{G}_{2}$ and $\mathrm{M}$ phases (28). Paclitaxel is a 
taxane that stabilizes microtubules in the mitotic spindle, blocking cell division and provoking apoptosis. In vivo preclinical studies revealed that inhibition of the mammalian target of rapamycin kinase (mTOR) decreased ${ }^{18} \mathrm{~F}$-FLT uptake in sensitive but not resistant tumors (32). In radiotherapy, dysregulation of the physiologic p53 tumor suppressor gene was associated with resistance to radiotherapy and a persistence of high levels of ${ }^{18} \mathrm{~F}$-FLT uptake after therapy, whereas intact p53 function was associated with tumor radiosensitivity and decreased ${ }^{18} \mathrm{~F}$-FLT uptake after therapy (33). Multiple preclinical in vivo studies revealed that ${ }^{18}$ F-FLT PET is effective in detecting the antiproliferative effects of therapeutic regimens $(25,34-46)$.

As a general rule, the changes in ${ }^{18}$ F-FLT uptake reported in these in vitro and preclinical in vivo studies occurred in the first $24 \mathrm{~h}$ of treatment, sometimes within a few hours. These exciting preclinical findings invite speculation that a patient might undergo ${ }^{18} \mathrm{~F}$-FLT PET on the same day as treatment initiation, and the PET data might predict the treatment response, allowing rapid changes in the therapeutic regimen, if needed.

\section{Clinical Studies with ${ }^{18} \mathrm{~F}-\mathrm{FLT}$}

Tumors often do not concentrate ${ }^{18} \mathrm{~F}-\mathrm{FLT}$ as avidly as ${ }^{18} \mathrm{~F}$ FDG (47). However, tumor delineation by ${ }^{18} \mathrm{~F}$-FLT PET appears to be superior to that by ${ }^{18} \mathrm{~F}-\mathrm{FDG}$ PET in certain viscera and anatomic regions, in which the physiologic (background) ${ }^{18} \mathrm{~F}$-FLT uptake level is much lower than that of ${ }^{18} \mathrm{~F}-\mathrm{FDG}$; these regions include the brain, mediastinum (including the heart), and intestines (intestinal ${ }^{18} \mathrm{~F}-\mathrm{FDG}$ concentrations are highly variable, ranging from nil to intense) $(48,49)$. Bone marrow ${ }^{18}$ F-FLT uptake is normally prominent, hampering the detection of osseous metastases; hence, ${ }^{18} \mathrm{~F}$-FDG PET may be superior to ${ }^{18} \mathrm{~F}$-FLT PET for evaluating the skeleton (49). ${ }^{18} \mathrm{~F}$-FDG PET evaluation of the skeleton after treatment is also often obscured by a diffuse prominence of bone marrow ${ }^{18} \mathrm{~F}$-FDG uptake induced by systemic chemotherapy or other endogenous or exogenous marrow stimuli (e.g., erythropoietic stimulants).

In a recent study, methods for measuring ${ }^{18} \mathrm{~F}$-FLT retention in patients with non-small cell lung cancer (NSCLC) were evaluated to assess measurement reproducibility (50). Nine patients with NSCLC that was not treated or that had progressed after previous therapy were imaged twice with ${ }^{18} \mathrm{~F}$-FLT within $2-7$ d. ${ }^{18} \mathrm{~F}$-FLT imaging results for patients with NSCLC were reproducible, with a worst-case mean standardized uptake value $\left(\mathrm{SUV}_{\text {mean }}\right)$ error of $21 \%$ when a short imaging time was used. However, reliance on a visual analysis or static measurement of ${ }^{18} \mathrm{~F}$-FLT is often problematic because transport and retention cannot be differentiated; therefore, several groups have compared full ${ }^{18} \mathrm{~F}$ FLT kinetic data analysis and SUV measurements (51-54).

In a pilot study, the precision of ${ }^{18} \mathrm{~F}-\mathrm{FLT}$ PET in quantifying therapy-induced reductions in cancer cell populations was examined (55). ${ }^{18} \mathrm{~F}$-FLT uptake in cancerous rectal tumors decreased after chemoradiation, but the ob- served decrease (during and 2 wk after therapy) did not differ between tumors with less than and tumors with greater than $10 \%$ residual viable cancer cells; differences in the percentages of residual viable cancer cells have prognostic implications (56).

\section{Response Prediction: Pretreatment Scanning Versus Posttreatment Scanning}

In an ${ }^{18}$ F-FLT PET clinical trial of patients with recurrent malignant glioma (Fig. 2), Chen et al. (57) found that changes in tumor ${ }^{18} \mathrm{~F}$-FLT uptake induced by $1-2$ wk of bevacizumab and irinotecan therapy were predictive of overall survival but that baseline tumor ${ }^{18} \mathrm{~F}$-FLT uptake was not; that is, a therapy-induced decrease in tumor ${ }^{18} \mathrm{~F}-$ FLT uptake identified patients who survived longer.

Herrmann et al. (58) measured changes in tumor ${ }^{18} \mathrm{~F}$-FLT uptake in patients with lymphoma (mostly diffuse large B-cell histology). Patients underwent ${ }^{18}$ F-FLT PET before treatment and after treatment; posttreatment scanning was performed twice, according to 1 of 2 schedules: group 1, at days 7 and 40 after the initiation of cyclophosphamideadriamycin-vincristine-prednisone chemotherapy, with or without rituximab immunotherapy; and group 2, $2 \mathrm{~d}$ after the initiation of rituximab therapy, with or without dexamethasone, and again $2 \mathrm{~d}$ after the initiation of cyclophosphamideadriamycin-vincristine-prednisone chemotherapy. Of 21 patients with follow-up data, 1 demonstrated progressive disease; all others demonstrated a complete $(n=14)$ or partial $(n=6)$ response. All patients demonstrated a reduction in ${ }^{18} \mathrm{~F}$-FLT uptake in lymphomatous disease. ${ }^{18} \mathrm{~F}$-FLT uptake after chemotherapy differed significantly between complete and partial responders (average SUVs, 1.5 and 2.6, respectively; $P=0.009$ ), whereas ${ }^{18} \mathrm{~F}-\mathrm{FLT}$ uptake before therapy did not. Patients with progressive disease demonstrated the smallest SUV decrease, $39 \%$; in comparison, the group mean $\pm \mathrm{SD}$ was $68 \% \pm 14 \%$. Interestingly, in group $2,{ }^{18} \mathrm{~F}-\mathrm{FLT}$ uptake never decreased after rituximab therapy alone; rather, it decreased only after the subsequent chemotherapy, suggesting that rituximab had no antiproliferative effects at the time of imaging. Because of the heterogeneity of the treatment regimens and ${ }^{18} \mathrm{~F}-\mathrm{FLT}$ PET schedules, it is difficult to draw statistically robust conclusions from the study.

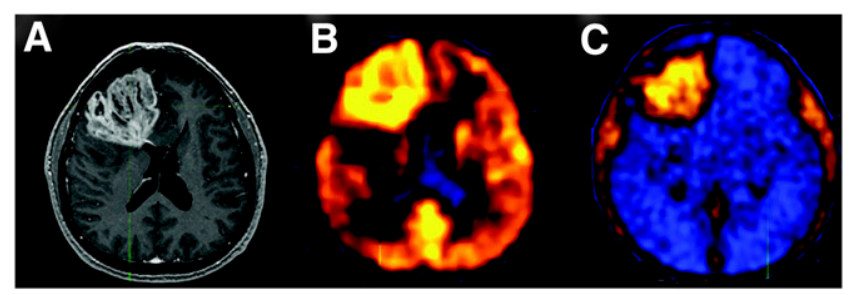

FIGURE 2. Newly diagnosed glioblastoma. (A) MRI (contrast-enhanced T1-weighted image) shows large area of contrast enhancement in right frontal lobe. (B and $\mathrm{C}$ ) Both ${ }^{18} \mathrm{~F}-\mathrm{FDG}$ PET (B) and ${ }^{18} \mathrm{~F}-\mathrm{FLT}$ PET (C) show increased uptake in same area. (Reprinted with permission of (189).) 


\section{Clinical Studies with ${ }^{18}$ F-FMAU}

The first pilot study of ${ }^{18} \mathrm{~F}-\mathrm{FMAU}$ in humans was conducted to determine its biodistribution and suitability for the imaging of DNA synthesis in tumors (59). Fourteen patients with diverse cancers (brain, prostate, colorectal, lung, and breast) underwent PET with ${ }^{18} \mathrm{~F}$-FMAU. Tumors in the breasts, brain, lungs, and prostate were clearly visualized, with SUVs of 2.19, 1.28, 2.21, and 2.27-4.42, respectively. Unlike PET with ${ }^{18} \mathrm{~F}$-FLT, PET with ${ }^{18} \mathrm{~F}$ FMAU revealed low tracer uptake in normal bone marrow $\left(\mathrm{SUV}_{\text {mean }}, 0.7\right)$, allowing the visualization of metastatic prostate cancer (SUV, 3.07); however, in the upper abdomen, visualization was limited by uptake in the liver and kidneys.

In preparation for clinical trials, the kinetics of ${ }^{18} \mathrm{~F}$ FMAU were studied to determine the most appropriate and simplest approach for image acquisition and analysis (60). Ten patients with brain $(n=4)$ and prostate $(n=6)$ tumors were imaged with ${ }^{18} \mathrm{~F}-\mathrm{FMAU}$, and tracer kinetics were measured by compartmental modeling. The $\mathrm{SUV}_{\text {mean }}$ and the maximum SUV on images obtained at 5-11 min correlated well with those on images obtained at 50-60 min. The quality of the images and the tissue kinetics after just 11 min of imaging demonstrated that ${ }^{18} \mathrm{~F}$-FMAU PET is a useful tumor imaging option.

\section{IMAGING OF HYPOXIA}

Since the 1930s, hypoxia (oxygen concentrations of $\leq 1,000 \mathrm{ppm}$ ) has been recognized as an important determinant in the physiology of solid tumors. The onset of hypoxia in malignant tissues is associated with undesirable outcomes, and it is well established that hypoxia is an important determinant of the overall response of a tumor to conventional therapy. Hypoxia can result in an increase in tumor aggressiveness, a failure of local control, and an activation of transcription factors that support cell survival and migration. The metastatic potential of solid tumors is believed to be highly associated with the presence of hypoxia (61). In addition, tumor hypoxia is associated with increased tumor aggressiveness, manifested as higher rates of recurrence and metastasis and resistance to chemotherapy (62-64). Therefore, the imaging of tumor hypoxia could result in a significant improvement in the care of patients with cancer $(65,66)$.

This review focuses on ${ }^{60 / 62 / 64} \mathrm{Cu}$-labeled diacetyl-bis ( $N^{4}$-methylthiosemicarbazone) $\left({ }^{60 / 62 / 64} \mathrm{Cu}\right.$-ATSM) and ${ }^{18} \mathrm{~F}$ fluoromisonidazole ( ${ }^{18} \mathrm{~F}$-FMISO), which are currently the 2 leading PET agents for the imaging of hypoxia. However, other radiopharmaceuticals with the potential to measure hypoxia are in various stages of development (66); these include ${ }^{18} \mathrm{~F}$ - or ${ }^{99 \mathrm{~m}}$ Tc-labeled agents now being evaluated in animal models and patients with solid tumors (67-71).

\section{Clinical Studies with Cu-ATSM}

The evolution of Cu-ATSM and in vitro, in vivo, and clinical studies of this tracer have been exhaustively reviewed (72). As discussed in detail by Vavere and Lewis (72), the mechanism of retention of $\mathrm{Cu}$-ATSM has been explored by several groups in the United States, Europe, and Japan (73-81). Simply stated, the reduction of $\mathrm{Cu}(\mathrm{II})-$ ATSM takes place in both normoxic and hypoxic cells, resulting in unstable $\mathrm{Cu}(\mathrm{I})$-ATSM. This unstable species slowly dissociates; if completely dissociated (in hypoxic cells), it becomes irreversibly trapped; however, in the presence of oxygen (normoxic cells), $\mathrm{Cu}(\mathrm{I})-\mathrm{ATSM}$ is reoxidized to $\mathrm{Cu}(\mathrm{II})-\mathrm{ATSM}$ and diffuses from the cells.

The first report of the use of Cu-ATSM in humans was published in 2000 for patients with lung cancer (82), and now several single-center studies have shown that ${ }^{60} \mathrm{Cu}-$ ATSM (Fig. 3A) accumulates avidly in hypoxic tissues (82-86). Clinical PET studies with ${ }^{60} \mathrm{Cu}$-ATSM have demonstrated an inverse relationship between the tumor uptake of this tracer and the response to therapy in patients with lung and rectal carcinomas and between the tumor uptake of this tracer and outcome in patients with cervical and rectal carcinomas (83-87).

To date, 38 patients with cancer of the uterine cervix have been imaged with ${ }^{60} \mathrm{Cu}$-ATSM PET (83). ${ }^{18} \mathrm{~F}-\mathrm{FDG}$ PET clinical studies demonstrated markedly increased ${ }^{18} \mathrm{~F}$ FDG uptake in the cervical cancers of all of these patients. ${ }^{60} \mathrm{Cu}$-ATSM showed high contrast levels between hypoxic and normoxic tissues by as little as 10-15 min after injection. The data were based on 30-60 min of summed data from the imaging session; the amount of tumor uptake of ${ }^{60} \mathrm{Cu}$-ATSM was variable. By use of a log-rank analysis of the previously reported data (87), it was found that a tumor-to-muscle (T/M) threshold of 3.5 was a statistically significant cutoff value for accurately differentiating patients whose cancer did not recur from those who developed a recurrence after completing therapy (Fig. 4). Progressionfree survival and cause-specific survival were significantly better in patients with a T/M for ${ }^{60} \mathrm{Cu}$-ATSM of $\leq 3.5(P=$ 0.006 and $P=0.04$, respectively) $(83,87)$.

In a study of 14 patients (men and women) with NSCLC, a semiquantitative analysis based on 30-60 min of summed data (the same as in the cervical cancer study) from the ${ }^{60} \mathrm{Cu}$-ATSM image was able to identify those likely to respond to therapy (84). In another pilot study, patients with locally invasive (T2-T4) primary or node-positive rectal cancer were imaged with ${ }^{60} \mathrm{Cu}$-ATSM PET; this imaging technique again demonstrated promise as a predictor of the

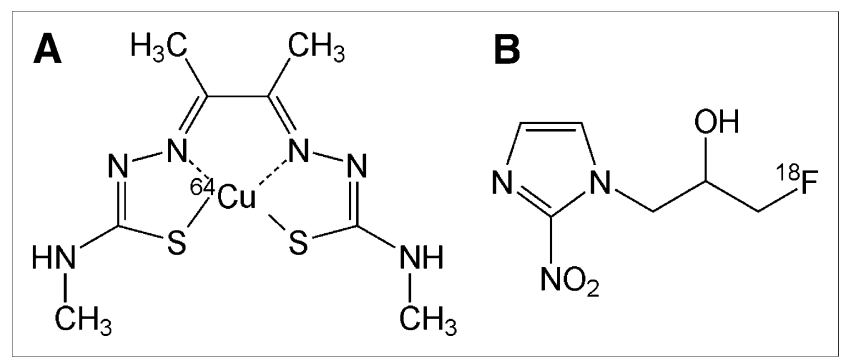

FIGURE 3. (A) ${ }^{64} \mathrm{Cu}-\mathrm{ATSM}$. (B) ${ }^{18} \mathrm{~F}-\mathrm{FMISO}$ 

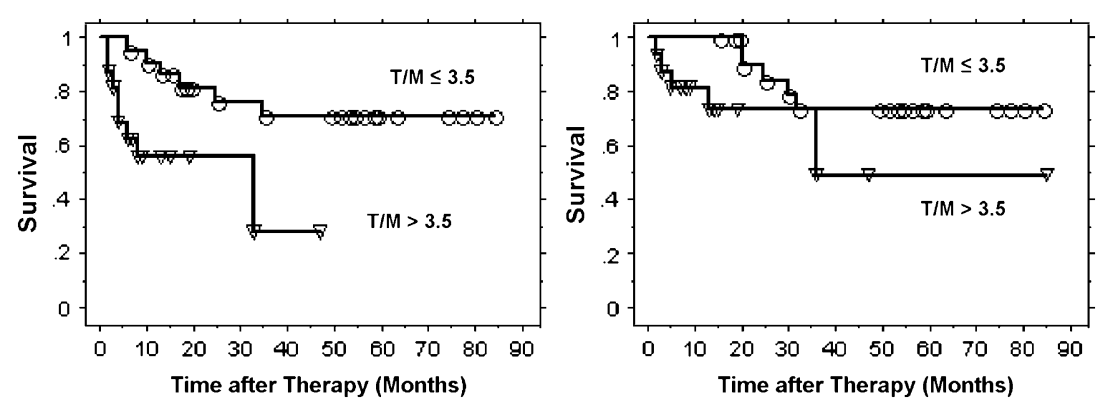

FIGURE 4. Progression-free survival (left) and cause-specific survival (right) determined from ${ }^{60} \mathrm{Cu}$-ATSM uptake by Kaplan-Meier method. $O=$ event in patients with $\mathrm{T} / \mathrm{M}$ of $\leq 3.5 ; \nabla=$ event in patients with $\mathrm{T} / \mathrm{M}$ of $>3.5$. (Reprinted with permission of (83).)

tumor response to neoadjuvant chemoradiotherapy and survival (85).

The initial clinical studies of ${ }^{60} \mathrm{Cu}-\mathrm{ATSM}(83-85,87)$ for cancers were done under the auspices of the Radioactive Drug Research Committee. To expand the use of ${ }^{64} \mathrm{Cu}-$ ATSM to other medical centers (to take advantage of the 12.7-h half-life of ${ }^{64} \mathrm{Cu}$ ), the first clinical study undertaken compared the quality of images obtained with ${ }^{60} \mathrm{Cu}$-ATSM (740 MBq) with the quality of images obtained with ${ }^{64} \mathrm{Cu}$ ATSM (925 MBq) (test-retest) for a cohort of 10 women with cervical carcinoma (Fig. 5) (86). The quality of images obtained with ${ }^{64} \mathrm{Cu}$-ATSM was found to be better than the quality of images obtained with ${ }^{60} \mathrm{Cu}$-ATSM because of less noise. In addition, the patterns and magnitudes of tumor uptake of ${ }^{60} \mathrm{Cu}$-ATSM and ${ }^{64} \mathrm{Cu}$-ATSM in PET studies separated by $1-9 \mathrm{~d}$ were found to be similar. $\mathrm{Cu}-$ ATSM has several well known advantages over other radiopharmaceuticals used for PET of hypoxia (72), including a simpler method for synthesis, faster clearance from normoxic tissue (allowing a short time between injection and imaging), and a simpler method for quantification. An additional advantage of ${ }^{64} \mathrm{Cu}$ is the fact that the technology for its production and widespread delivery is commercialized (88).

\section{${ }^{18}$ F-Fluoromisonidazole ( $\left.{ }^{18} \mathrm{~F}-\mathrm{FMISO}\right)$}

Investigations over the last 2 decades have led to quantitative, noninvasive methods for PET and SPECT of hypoxia $(89,90)$, with much of the work focusing on labeled nitroimidazoles, a class of compounds whose metabolism and tissue retention are dependent on tissue oxygenation. After entering a viable cell, nitroimidazoles are reduced to $\mathrm{RNO}_{2}$ radicals, regardless of the intracellular oxygen concentration. In the presence of tissue oxygen, the radical is immediately reoxidized, and the original uncharged compound leaves the cell. If intracellular oxygen levels are low, however, the $\mathrm{RNO}_{2}$ radical is further reduced to a more reactive form, which binds covalently to intracellular macromolecules and remains within the cell. The most extensively studied radiolabeled nitroimidazole for in vivo PET is ${ }^{18}$ F-FMISO (Fig. 3B) (91-94), which is lipophilic and therefore diffuses readily through cell membranes. Tissue hypoxia has been defined as an ${ }^{18} \mathrm{~F}$-FMISO tissue-to-blood (T/B) ratio of $\geq 1.2$ by $2 \mathrm{~h}$ after radiotracer administration, as determined from biodistribution studies in both animals and humans (91). Also, for low-oxygen-dependent ${ }^{18} \mathrm{~F}$ FMISO binding to occur, hypoxic regions must have $\mathrm{pO}_{2}$ levels below $2-3 \mathrm{~mm} \mathrm{Hg}(\sim 2,600-4,000 \mathrm{ppm})$ to cause substantial retention (95).

\section{Clinical Studies with ${ }^{18} \mathrm{~F}-\mathrm{FMISO}$}

Rasey et al. used ${ }^{18}$ F-FMISO to study 37 cancer patients before therapy. Elevated ${ }^{18} \mathrm{~F}-\mathrm{FMISO} \mathrm{T} / \mathrm{B}$ ratios $(\geq 1.4)$ observed in tumors were used to estimate the fractional hypoxic volume (HV) (94). Hypoxia was found in the tumors of 36 of 37 subjects, and fractional HVs ranged from $0 \%$ to $94.7 \%$.

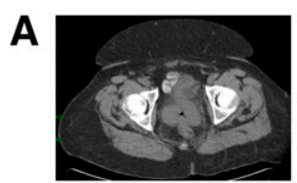

CT

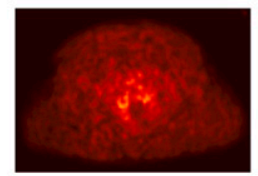

${ }^{60} \mathrm{CU}-\mathrm{ATSM}$ PET

$\mathrm{T} / \mathrm{M}=3.5$

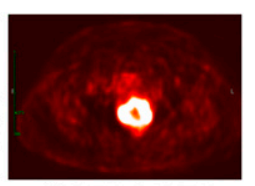

${ }^{18}$ F-FDG PET

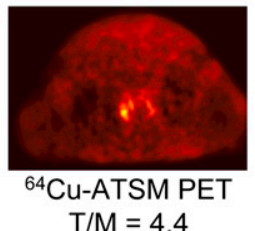

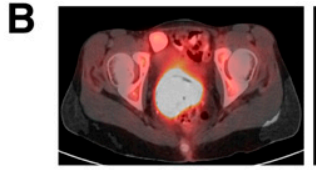
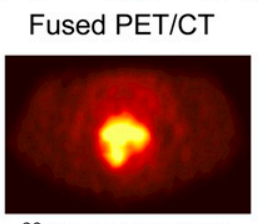

${ }^{60} \mathrm{Cu}-\mathrm{ATSM}$ PET $\mathrm{T} / \mathrm{M}=8.1$

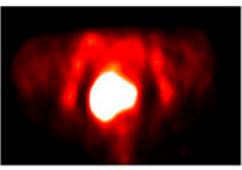

${ }^{18} \mathrm{~F}-\mathrm{FDG}$ PET

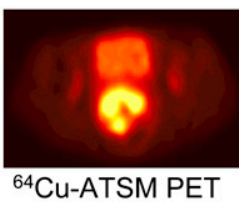

$\mathrm{T} / \mathrm{M}=10.3$
FIGURE 5. (A) Transaxial CT (top left) and ${ }^{18} \mathrm{~F}$-FDG PET (top right) images of pelvis show intense ${ }^{18} \mathrm{~F}-\mathrm{FDG}$ uptake within known cervical tumor at site of cervical mass seen on CT. Transaxial 30- to 60-min summed images of ${ }^{60} \mathrm{Cu}$ ATSM PET (bottom left) and ${ }^{64} \mathrm{Cu}-\mathrm{ATSM}$ PET (bottom right) of pelvis at same level demonstrate mildly increased uptake within known primary cervical tumor. There are similar patterns of ${ }^{60} \mathrm{Cu}$-ATSM and ${ }^{64} \mathrm{Cu}$-ATSM uptake within tumor. (B) Transaxial coregistered ${ }^{18} \mathrm{~F}-\mathrm{FDG}$ PET/CT (top left) and ${ }^{18} \mathrm{~F}-\mathrm{FDG}$

PET (top right) images of pelvis show intense ${ }^{18} \mathrm{~F}-\mathrm{FDG}$ uptake within known cervical tumor at site of cervical mass seen on CT. Transaxial 30- to 60-min summed images of ${ }^{60} \mathrm{Cu}$-ATSM PET (bottom left) and ${ }^{64} \mathrm{Cu}$-ATSM PET (bottom right) of pelvis at same level demonstrate markedly increased uptake within known primary cervical tumor. There are similar patterns of ${ }^{60} \mathrm{Cu}-\mathrm{ATSM}$ and ${ }^{64} \mathrm{Cu}-\mathrm{ATSM}$ uptake within tumor. (Reprinted with permission of (86).) 
The extent of hypoxia varied markedly among tumors, and the distribution of hypoxia was heterogeneous in tumors at the same site or with the same histology. In more recent studies, Rajendran et al. showed that the results of ${ }^{18} \mathrm{~F}$ FMISO PET before therapy were predictive of survival in patients with head and neck cancer (96), and Spence et al. showed that hypoxia in glioblastoma multiforme, as determined by ${ }^{18} \mathrm{~F}$-FMISO PET, was strongly associated with poorer results for time to progression (TTP) and survival (97). In the study by Spence et al., the tumor HV and the maximum level of hypoxia in glioblastoma multiforme were measured by ${ }^{18} \mathrm{~F}$-FMISO PET before radiotherapy to assess the impact of hypoxia on the TTP and survival (97). Spence et al. studied 22 patients before biopsy or between resection and initiation of radiotherapy; all patients underwent a $20-\mathrm{min}$ emission scan $2 \mathrm{~h}$ after intravenous injection of $\sim 260 \mathrm{MBq}$ of ${ }^{18}$ F-FMISO (Fig. 6) (97). T/B ratios above 1.2 were again

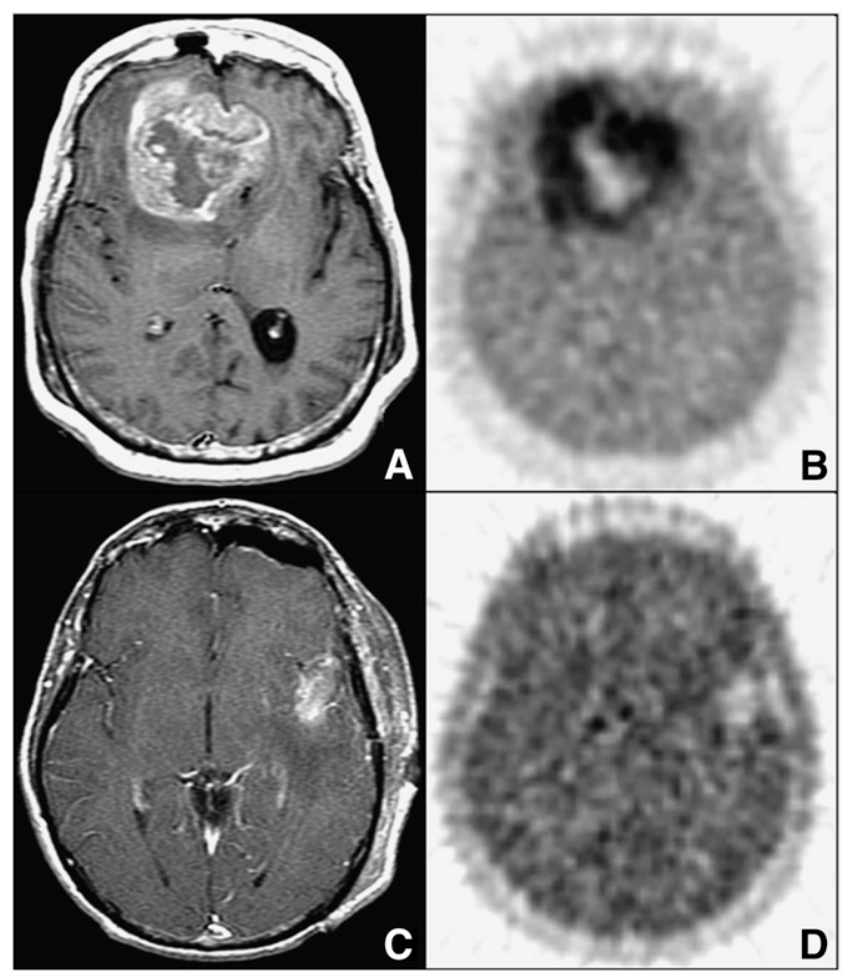

FIGURE 6. (A and B) Bifrontal glioblastoma multiforme imaged after biopsy in 55-y-old woman. (A) MRI (gadoliniumenhanced T1-weighted image [T1Gd]) shows large, contrastenhancing, irregular ring-shaped tumor with necrotic center. Non-contrast-enhanced volume was $20 \mathrm{~cm}^{3}$, T1Gd volume was $80 \mathrm{~cm}^{3}$, and T2-weighted volume was $167 \mathrm{~cm}^{3}$. (B) ${ }^{18} \mathrm{~F}-$ FMISO image through same plane. HV was $129 \mathrm{~cm}^{3}$, and T/ $B_{\max }$ ratio was 3.0. (C and $\left.D\right)$ Left temporal glioblastoma multiforme imaged after gross total resection in 53-y-old man. (C) MRI (T1Gd) shows only blood products and no residual contrast-positive disease. Non-contrast-enhanced volume was $1 \mathrm{~cm}^{3}$, T1Gd volume was $7 \mathrm{~cm}^{3}$, and T2weighted volume was $37 \mathrm{~cm}^{3}$. (D) ${ }^{18} \mathrm{~F}-\mathrm{FMISO}$ image through same plane. $\mathrm{HV}$ was $5.3 \mathrm{~cm}^{3}$, and $\mathrm{T} / \mathrm{B}_{\max }$ ratio was 1.6 . (Reprinted with permission of (97).) used to define the tumor $\mathrm{HV}$, and the maximum $\mathrm{T} / \mathrm{B}\left(\mathrm{T} / \mathrm{B}_{\max }\right)$ ratios were determined from the pixel with the highest uptake. Kaplan-Meier plots demonstrated shorter TTP and survival in patients whose tumors had $\mathrm{HVs}$ or $\mathrm{T} / \mathrm{B}_{\max }$ ratios greater than the median $(P \leq 0.001)$. Overall, both higher HVs and $\mathrm{T} / \mathrm{B}_{\max }$ ratios in glioblastoma multiforme, as measured by ${ }^{18} \mathrm{~F}$-FMISO PET, before radiotherapy were strongly associated with poorer results for TTP and survival.

The reproducibility of the intratumoral distribution of ${ }^{18} \mathrm{~F}-\mathrm{FMISO}$ was recently examined more closely in 30 patients with head and neck cancer (98). All patients underwent an ${ }^{18} \mathrm{~F}-\mathrm{FDG}$ study and then $2{ }^{18} \mathrm{~F}$-FMISO studies $3 \mathrm{~d}$ apart. As with the other clinical studies already described, the HVs were delineated according to a T/M ratio of $\geq 1.2$. A voxel-by-voxel analysis of the ${ }^{18} \mathrm{~F}$-FMISO distributions in the entire tumor volume showed a strong correlation in $71 \%$ of the head and neck tumors; restraining the correlation to putatively hypoxic zones reduced the number of tumors exhibiting a strong correlation to $46 \%$. That study might have been the first in which variability in spatial uptake was shown to occur between repeat ${ }^{18} \mathrm{~F}$ FMISO PET scans of patients. Of 13 patients, 6 had wellcorrelated intratumoral distributions of ${ }^{18} \mathrm{~F}$-FMISO suggestive of chronic hypoxia; however, more work is required to identify the underlying causes of changes in intratumoral distribution before single-time-point ${ }^{18} \mathrm{~F}$-FMISO PET images can be used as the basis of hypoxia-targeting intensity-modulated radiotherapy.

At present, there is no established method for identifying patients who will benefit from hypoxia-directed therapy. However, Rischin et al. recently demonstrated that ${ }^{18} \mathrm{~F}-$ FMISO PET is useful in directing hypoxia-specific treatment in patients with head and neck cancer; the uptake of ${ }^{18} \mathrm{~F}$-FMISO predicted the greater effectiveness of tirapazamine therapy than of a non-tirapazamine-containing regimen (99). In that study, only patients with increased ${ }^{18} \mathrm{~F}$-FMISO uptake benefited from the addition of tirapazamine to radiotherapy.

Many studies have demonstrated that an in vivo assessment of tumor hypoxia is possible with ${ }^{18} \mathrm{~F}-\mathrm{FMISO}$ $(93,97,100,101)$, but the unfavorable imaging characteristics of this compound have limited its use in clinical oncology. The main advantage of ${ }^{18} \mathrm{~F}$-FMISO is that it is directly affected by tumor oxygenation, but the compound has 2 major limitations. One is the limited contrast ratio between hypoxic tumors and normal tissues (T/B ratio of $>1.2$ ), reflecting the poor tissue uptake of ${ }^{18} \mathrm{~F}$-FMISO in vivo. The other is the slow cellular washout of this tracer; a delay of approximately $2 \mathrm{~h}$ after the injection of ${ }^{18} \mathrm{~F}$-FMISO is needed to permit the clearance of this tracer from normal background tissues. Although this property delays imaging and results in low-counting-rate studies and images of limited quality $(93,100,102)$, it has been demonstrated that meaningful data can be generated in clinical situations $(93,94,97)$. Other nitroimidazole-based ${ }^{18} \mathrm{~F}$-radiopharmaceuticals have been investigated (100); ${ }^{18} \mathrm{~F}$-fluoroazomycin arabinoside, the 
most recently studied of these agents, shows uptake similar to that of ${ }^{18}$ F-FMISO but better blood clearance (70).

\section{AMINO ACID TRACERS}

PET with L-[methyl- $\left.{ }^{11} \mathrm{C}\right]$ methionine $\left({ }^{11} \mathrm{C}-\mathrm{MET}\right)$ is the most popular amino acid imaging modality in oncology, with reports in over 250 basic scientific and clinical publications. A recent exhaustive review by Singhal et al. focused on the role of ${ }^{11} \mathrm{C}$-MET PET in the imaging of cerebral gliomas, the application of greatest interest (103). The biologic background of tumor imaging with methionine was discussed, with particular emphasis on cellular amino acid transport, amino acid use in the brain, the normal metabolism of methionine, and its alterations in cancer. Therefore, the mechanism of action of methionine is not the focus of this review. Singhal et al. also thoroughly discussed the roles of ${ }^{11} \mathrm{C}-\mathrm{MET}$ PET in the clinical management of cerebral gliomas: initial diagnosis, differentiation of tumor recurrence from radiation injury, grading, prognostication, delineation of tumor extent, biopsy planning, surgical resection and radiotherapy planning, and assessment of the response to therapy (103). Therefore, we provide only a few examples of the use of ${ }^{11} \mathrm{C}$-MET PET in the monitoring of therapy.

In 2006, Galldiks et al. monitored the metabolic effects of temozolomide (TMZ) chemotherapy for malignant gliomas by means of repeat ${ }^{11} \mathrm{C}$-MET PET scans (104). Fifteen patients with histologically proven malignant gliomasoligoastrocytoma ( $n=6$, World Health Organization [WHO] grade III; and $n=1$, WHO grade II), astrocytoma $(n=3$, WHO grade III), glioblastoma $(n=3$, WHO grade IV), and oligodendroglioma ( $n=2, \mathrm{WHO}$ grade III)-were treated with TMZ chemotherapy. ${ }^{11} \mathrm{C}-\mathrm{MET}$ PET studies were performed before and after the third cycle of TMZ chemotherapy in all patients and after the sixth cycle in 12 patients as well. The long-term outcome was assessed by calculating the TTP of the disease. As determined by ${ }^{11} \mathrm{C}$ MET PET, a decline in uptake during therapy corresponded to a stable clinical status; the median TTP was significantly longer in patients with decreasing ${ }^{11} \mathrm{C}$-MET uptake than in those with increasing ${ }^{11} \mathrm{C}$-MET uptake (23 vs. $3.5 \mathrm{mo} ; P=$ 0.01 , as determined by log-rank test). Their data demonstrated that clinical stability, which is often achieved with TMZ chemotherapy of malignant gliomas, corresponded to a decline in or the stability of tumor amino acid metabolism and that a reduction in ${ }^{11} \mathrm{C}-\mathrm{MET}$ uptake during $\mathrm{TMZ}$ treatment predicted a more favorable clinical outcome.

Lee et al. undertook a study to determine whether increased uptake on ${ }^{11} \mathrm{C}$-MET PET scans obtained before radiation therapy and $\mathrm{TMZ}$ was associated with the site of subsequent failure in newly diagnosed glioblastoma multiforme (105). Patients with primary glioblastoma multiforme were treated in a prospective trial with dose-escalated radiation and concurrent TMZ. Automated image registration was used to assess whether areas of increased ${ }^{11} \mathrm{C}$ -
MET PET activity were fully encompassed by the high-dose region. Overall, 26 patients were evaluated, and 19 had appreciable $\left(>1 \mathrm{~cm}^{3}\right)$ volumes of increased ${ }^{11} \mathrm{C}$-MET PET activity before treatment. Overall, pretreatment ${ }^{11} \mathrm{C}-\mathrm{MET}$ PET appeared to identify areas at the highest risk for recurrence in patients with glioblastoma multiforme; therefore, it would be reasonable to test a strategy of incorporating ${ }^{11} \mathrm{C}$ MET PET into radiation treatment planning, particularly for identifying areas for conformal radiation boost.

During a course of radiotherapy, it is of paramount importance to differentiate recurrent brain tumors from radiation necrosis. In 2008, Terakawa et al. evaluated the diagnostic accuracy of ${ }^{11} \mathrm{C}$-MET PET for differentiating recurrent brain tumors from radiation necrosis in 77 patients who had been treated with radiotherapy after primary treatment for metastatic brain tumor $(n=51)$ or glioma $(n=26)$ (Fig. 7) (106). Pathologic examination provided a definitive diagnosis for recurrent brain tumors or a clinical course for radiation necrosis. It was elegantly demonstrated that the values for each measured index of ${ }^{11} \mathrm{C}$-MET PET tended to be higher for tumor recurrence than for radiation necrosis and that ${ }^{11} \mathrm{C}$-MET PET could provide quantitative values to help differentiate tumor recurrence from radiation necrosis. The findings indicated that quantitative analysis of ${ }^{11} \mathrm{C}$-MET PET data may be helpful in managing irradiated brain tumors.

The short half-life of ${ }^{11} \mathrm{C}$ prevents the widespread use of ${ }^{11} \mathrm{C}$-MET PET for tumor imaging; awareness of this limitation has stimulated the development and evaluation of ${ }^{18} \mathrm{~F}$-labeled amino acids. A few clinical studies have demonstrated the suitability of ${ }^{18} \mathrm{~F}$-fluorophenylalanine (107) and $\mathrm{L}^{\mathrm{L}}-2-{ }^{18} \mathrm{~F}-$ fluorotyrosine (108) for tumor imaging, but these investigations have not been expanded. In 1999, a nonmetabolizable analog of tyrosine, $\mathrm{O}$ - $\left(2-{ }^{18} \mathrm{~F}\right.$-fluoroethyl)-L-tyrosine $\left({ }^{18} \mathrm{~F}\right.$ FET) (109), and a nonmetabolizable amino acid, ${ }^{18} \mathrm{~F}$-labeled 1-amino-3-fluoro-cyclobutane carboxylic acid ( ${ }^{18} \mathrm{~F}$-FACBC),

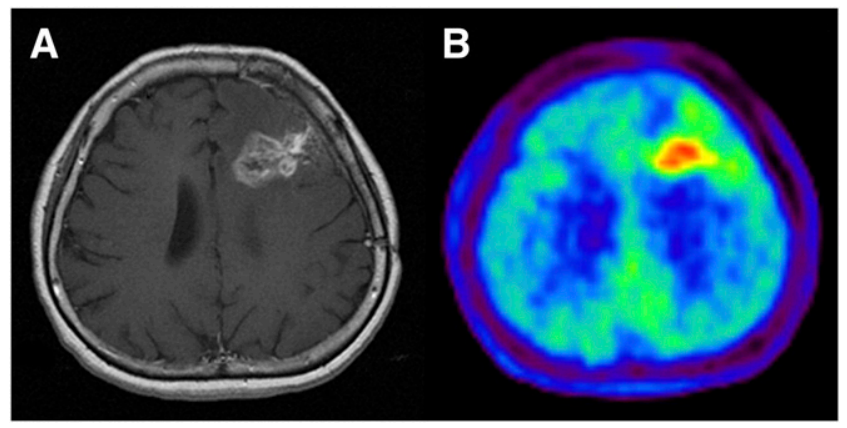

FIGURE 7. Imaging of 49-y-old woman who had been previously treated for glioblastoma multiforme with tumor resection and conventional radiotherapy at dose of 60 Gy. (A) T1-weighted MR image obtained with contrast medium 13 mo after initial surgery showed contrast-enhanced lesion in left frontal lobe. (B) ${ }^{11} \mathrm{C}-\mathrm{MET}$ PET image showed obvious accumulation of tracer corresponding to abnormality on MR image. Mean lesion-to-normal tissue ratio was 1.70. Recurrent tumor was pathologically confirmed by second surgery. (Reprinted with permission of (106).) 
were prepared in high yields $(110,111)$. In initial clinical studies of brain tumors, ${ }^{18} \mathrm{~F}$-FET PET compared favorably with ${ }^{11} \mathrm{C}$-MET PET $(112,113)$. Although the study of ${ }^{18} \mathrm{~F}$-FET PET focused mainly on brain tumors, 2 preliminary studies also investigated the use of ${ }^{18} \mathrm{~F}$-FET PET for peripheral tumors (113) and head and neck cancer (114). Both studies stated that ${ }^{18}$ F-FET may not replace ${ }^{18}$ F-FDG for diagnostic PET of head and neck cancer but that it may be a helpful additional tool in selected patients because it may better differentiate tumor tissue from inflammatory tissue. The initial pilot human studies with ${ }^{18} \mathrm{~F}-\mathrm{FACBC}$ are encouraging (110,115-117), and it will be interesting to learn how both ${ }^{18} \mathrm{~F}$-FET and ${ }^{18} \mathrm{~F}$ FACBC can be used for monitoring therapeutic outcomes.

\section{HORMONE RECEPTOR IMAGING}

Hormonal therapy has a major role in cancer care, particularly for prostate and breast cancer patients. Clinical trials of PET imaging of tumor expression of androgen receptors in prostate cancer patients are currently under way. Imaging of tumor expression of ERs by PET and of human epidermal growth factor receptor 2 (HER2) by PET and SPECT is also under way in trials predominantly involving breast cancer patients but also in studies involving uterine tumors $(118,119)$ and meningiomas $(120)$. In general, these trials have demonstrated the feasibility of quantifying receptor expression by scintigraphy, but only for PET of tumor ER expression has a significant amount of published data been gathered concerning the potential for evaluating tumor responsiveness to hormonal therapy.

The ability to noninvasively assess ER status in all tumors-particularly in metastatic disease, which poses the most danger to a patient-would clearly be advantageous clinically for several reasons. In breast cancer, the expression of ERs by tumor cells predicts mortality (121) and the efficacy of antiestrogen-ER treatments (122) and (nonhormonal) chemotherapy (123). Receptor expression in easily biopsied primary breast tumors can differ from that in less accessible metastatic tumors $(124,125)$. Tumors that were initially ER positive can become ER negative in the setting of recurrence in as many as $36 \%$ of cases (126). Finally, the development of resistance to endocrine therapy in breast cancer often involves changes in ER and HER2 expression, a fact that provides a clear role for both ER imaging and HER2 imaging in monitoring therapeutic responses (see the excellent review by Zilli et al. (127)). The 2007 guidelines of the American Society of Clinical Oncology describe recommended clinical uses of ER and HER2 expression assays (128). Unlike standard tissue assays, imaging offers the ability to quantify ER expression and occupancy; this feature could be exploited to select and titrate drug dosages in individual patients with the goal of ER saturation.

16- $\alpha-{ }^{18}$ F-Fluoro-17- $\beta$-Estradiol (18 F-FES)

Radiotracers for imaging ERs have been clinically tested for over 2 decades (129), and ${ }^{18}$ F-FES has emerged as the leading contender (Fig. 8A). After intravenous injection, blood levels of circulating radioactivity achieve stability quickly, in 20-30 min (130). Like estradiol, circulating ${ }^{18} \mathrm{~F}$-FES is protein bound to albumin or sex steroid-binding protein (SSBP; also known as sex hormone-binding globulin) (131). The majority ( $~ 80 \%)$ of circulating radioactivity consists of ${ }^{18} \mathrm{~F}$-FES metabolites (which do not bind to protein) (131) from 30 to $60 \mathrm{~min}(120,131)$. Therefore, attempts to quantify tissue concentrations of ERs in tumors must use pharmacokinetic models that account for ${ }^{18} \mathrm{~F}-\mathrm{FES}$ protein binding and metabolites $(120,131)$. Still, clinical studies have demonstrated that semiquantitative PET measurements of ${ }^{18} \mathrm{~F}$-FES concentrations in tumors show fair correlations with ER concentrations measured ex vivo by conventional immunohistochemistry (132) or ligand-binding assays $(133,134)$; quantitative analyses involving prolonged, dynamic PET may not offer significant additional information beyond that offered by simpler, static PET (120).

When considering the strength of reported histologic correlations, readers should remember that the accuracy or reproducibility of ex vivo ER assays is imperfect $(120,135)$. Therefore, it is perhaps more proper to state that ${ }^{18} \mathrm{~F}$-FES visualizes available ERs. In rodents, endogenous estradiol has a 10 -fold-higher affinity than ${ }^{18} \mathrm{~F}$-FES for sex steroidbinding protein and a higher affinity for ERs (136-138). High blood levels of exogenous estradiol are able to displace ${ }^{18}$ F-FES from tumor receptors completely (139); to what extent endogenous estradiol levels affect tumor ${ }^{18} \mathrm{~F}$ FES uptake has not yet been reported. Similarly, estradiol displacement of ${ }^{18} \mathrm{~F}$-FES from binding to SSBP may affect an important component of tumor ${ }^{18} \mathrm{~F}$-FES uptake because steroid delivery to cells involves receptor-mediated transport of steroid bound to SSBP (131). This consideration is important with regard to the study of Dehdashti et al., who correlated pretreatment tumor ${ }^{18} \mathrm{~F}$-FES uptake with the response to aromatase inhibitors $(n=40)$ or fulvestrant ( $n=11$ ) (140). Like tamoxifen, fulvestrant binds ERs, preventing estradiol binding. Aromatase inhibitors (e.g., anastrazole, exemestane, and letrozole) block the enzyme aromatase in nonovarian tissues; aromatase catalyzes estrogen production.

\section{Clinical Studies with ${ }^{18}$ F-FES}

Several clinical studies have examined the prognostic significance of tumor ${ }^{18} \mathrm{~F}-\mathrm{FES}$ concentrations by use of semiquantitative PET SUV scores in breast cancer patients

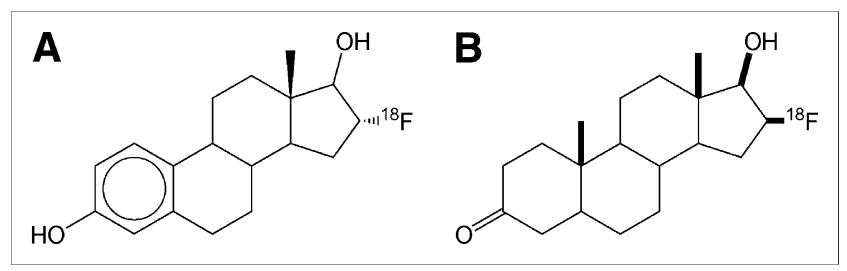

FIGURE 8. (A) ${ }^{18} \mathrm{~F}-\mathrm{FES}$. (B) ${ }^{18} \mathrm{~F}-\mathrm{FDHT}$. 
(140-145). Low levels of tissue ${ }^{18} \mathrm{~F}-\mathrm{FES}$ avidity (e.g., tumor maximum SUVs of <1-2) $(120,133,140,141,144)$ have been considered negative for ER expression, that is, negative for the expression of $\mathrm{ER} \alpha$, which is the specific target of conventional ER immunohistochemistry (127). The average pretherapy tumor ${ }^{18}$ F-FES SUV scores for responders and nonresponders, as groups, were sufficiently different to achieve statistical significance in these studies, but the magnitude of the average difference was not great $(140,143)$. Pretreatment tumor uptake values at the high and low ends of the range of SUV scores had clear implications: very high tumor SUVs identified disease that would respond, and very low SUVs predicted nonresponsive disease $(140,143)$. However, the middle region of the range of SUV scores was fairly broad and had less predictive value. The considerable overlap of responsive and nonresponsive tumor SUV scores is illustrated, for example, in the study of Dehdashti et al., in which nonresponders had a pretherapy $\mathrm{SUV}_{\text {mean }}$ score of $2.1 \pm 1.8$ and responders had a pretherapy $\mathrm{SUV}_{\text {mean }}$ score of $3.5 \pm 2.5$ (Fig. 9) (140). That study showed that the likelihood of a tumor response increased with each unit increase in the tumor ${ }^{18}$ F-FES SUV score (140).

\section{Have Pretreatment Threshold SUV Scores Been Suggested for Accurate Discrimination of Responses to Endocrine Therapy?}

The appropriate threshold likely varies, depending on the specific therapeutic regimen used as well as clinical and histologic variables other than ER status (140). Dehdashti et al., studying postmenopausal ER-positive breast cancer patients, prospectively validated a tumor SUV score of $\geq 2.0$ as offering optimal accuracy in predicting the response to aromatase inhibitors $(n=40)$ or fulvestrant $(n=$ 11), with a sensitivity of $70 \%$ and a specificity of $64 \%$ for predicting a favorable response (140). In that study, most patients had previous endocrine therapy, including tamoxifen and aromatase inhibitors; the authors did not specify what time interval separated the "pretherapy" ${ }^{18} \mathrm{~F}-\mathrm{FES}$ PET scan and the last endocrine therapy. Hence, it is unclear whether drugs with long clearance times (e.g., 4-6 wk for tamoxifen) might still have been in the patients' blood circulation at the time of the pretherapy ${ }^{18} \mathrm{~F}$-FES PET scan; if so, tumor ${ }^{18} \mathrm{~F}$-FES uptake could have been altered, confusing or weakening correlations with responses to subsequent therapy. Dehdashti et al. noted that they found stronger correlations between pretherapy tumor ${ }^{18} \mathrm{~F}$-FES uptake and responses to therapy in a previous study involving a hormone-naive population (140).

Because antiestrogen therapy can be potently efficacious and its toxicity profile is relatively benign compared with those of chemotherapeutic alternatives (122), it may be especially important to determine an SUV threshold that is highly sensitive, identifying all patients with a potential to benefit from an antiestrogen-ER regimen, even if the specificity is poor. A tumor SUV score of less than 1.0 appears to be a highly sensitive threshold for identifying patients who will not benefit from antiestrogen-ER therapy $(140,142)$.

\section{Do Therapy-Induced Changes in Tumor ${ }^{18}$ F-FES SUV Scores Predict Responses?}

Mortimer et al. examined this question, comparing tumor ${ }^{18}$ F-FES SUV scores before treatment and 7-10 d into tamoxifen therapy (143). Tamoxifen and its metabolites bind to ERs, preventing estrogen (and ${ }^{18} \mathrm{~F}$-FES) binding to cancer cells. As in the later study of Dehdashti et al. (140), Mortimer et al. (143) found that the nonresponsive group had a relatively low pretherapy tumor SUV score $(1.8 \pm 1.4)$ compared with the responsive group $(4.3 \pm 2.4)(P=0.0007)$. The responders demonstrated a greater decrease in SUVs in response to tamoxifen than did the nonresponders: $-55 \% \pm$ $14 \%$ versus $-19 \% \pm 17 \%$, respectively $(P=0.0003)$. Was this decrease in tumor ${ }^{18} \mathrm{~F}$-FES concentrations attributable to tamoxifen occupancy of ERs or induced downregulation of ERs, or had tumor cells begun dying after 7-10 d of treatment, so that fewer total ERs were present inside tumors? Preclinical research has suggested that significant tamoxifen-
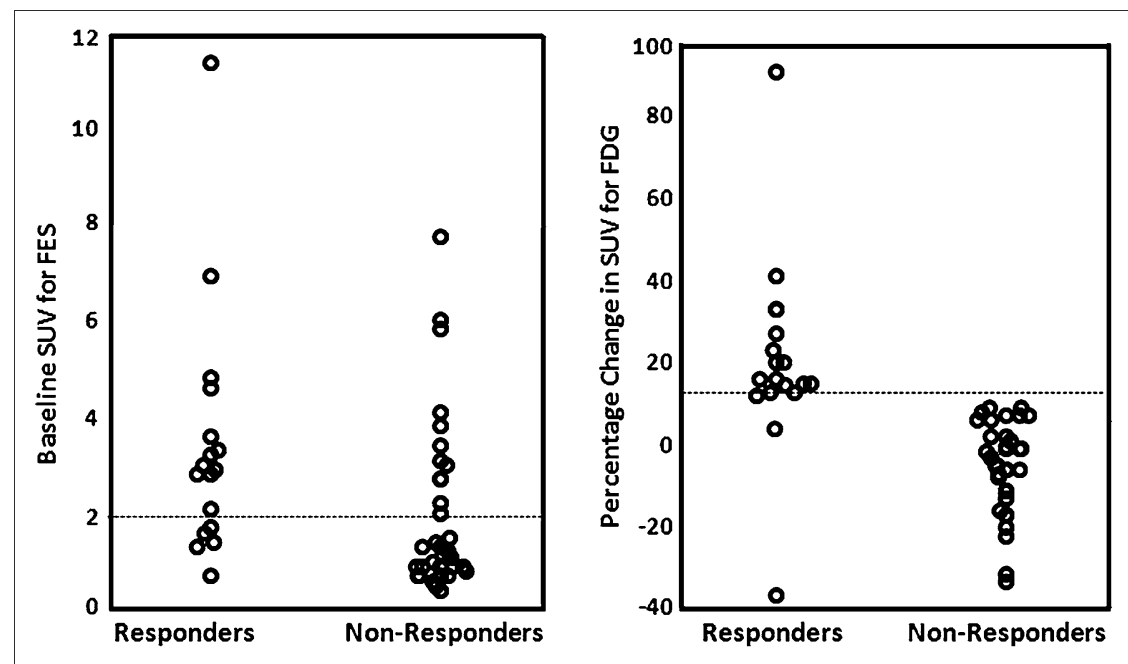

FIGURE 9. Baseline tumor ${ }^{18} \mathrm{~F}-\mathrm{FES}$ (left) and percentage change in tumor ${ }^{18} \mathrm{~F}-\mathrm{FDG}$ (right) uptake after estradiol challenge in patients who responded and patients who did not respond to endocrine therapy. (Reprinted with permission of (140).) 
induced tumor apoptosis occurs later, 3-4 wk after treatment begins (146). Research has indicated that tamoxifen induces an acute downregulation of ER availability $(147,148)$. Although it takes 3-5 wk to achieve stable serum levels of tamoxifen $(149,150)$, serial ${ }^{18}$ F-FES PET could be used to titrate tamoxifen dosages in individual patients toward tumor saturation in the hope of improving responses while avoiding dosages that exceed the saturation point and may needlessly increase the risk of toxicity. Animal studies have suggested the feasibility of tamoxifen titration by ${ }^{18} \mathrm{~F}-$ FES PET (139). Were an ${ }^{18}$ F-FES PET approach to be pursued, "loading" doses of tamoxifen could be used to achieve steady-state levels more rapidly (150) and to establish new, higher dosage levels; however, reducing dosage levels may require a 4 - to 6-wk delay for ${ }^{18}$ F-FES PET reassessment, given the long half-life of tamoxifen (150).

Although these studies validate serial ${ }^{18} \mathrm{~F}-\mathrm{FES}$ PET as an assay for predicting the response to endocrine therapy in a patient population, the significance of changes in ${ }^{18} \mathrm{~F}-\mathrm{FES}$ SUV scores in individual patients remains nebulous for percentage changes in the intermediate range. No clinical reports have yet described the intrapatient reproducibility of ${ }^{18} \mathrm{~F}-\mathrm{FES}$ SUV scores (e.g., by repeat pretherapy ${ }^{18}$ F-FES PET scans obtained on 2 consecutive days). Knowing the reproducibility of ${ }^{18} \mathrm{~F}$-FES SUV scores would provide clinicians with a gauge for the precision of ${ }^{18} \mathrm{~F}$-FES PET and for which changes can be attributed to mere test variability (i.e., artifacts).

Finally, because the clinical emergence of tumor resistance to antiestrogen-ER therapy appears to involve the downregulation of ER expression and the upregulation of HER2 expression (151), a role for HER2 imaging is suggested. Detection of the upregulation of tumor HER2 expression by imaging may indicate the emergence of a resistance phenotype. Inhibition of HER2 may restore sensitivity to antiestrogen-ER therapy (151).

\section{$16 \beta-{ }^{18} \mathrm{~F}-F l u o r o-5 \alpha$-Dihydrotestosterone ( ${ }^{18} \mathrm{~F}-\mathrm{FDHT}$ )}

${ }^{18} \mathrm{~F}$-FDHT (Fig. 8B) is an analog of $5 \alpha$-dihydrotestosterone, the main prostatic form of androgen. Imaging of androgen receptor expression in prostate cancer has at least 2 potential roles in evaluating the response to therapy. First, focal ectopic expression of androgen receptors may be a more tumor-specific manifestation of prostate metastases than other commonly used imaging characteristics (e.g., osseous activity on bone scintigraphy, hyperattenuation on CT, and combinations of MRI signal patterns) and may allow better disease staging and therapeutic response assessment. Imaging of the therapeutic response for patients with metastatic prostate cancer is complicated by the predilection of prostate metastases for bone. Bone metastases are considered nonmeasurable by the standard international tumor response criteria (Response Evaluation Criteria in Solid Tumors [RECIST]) $(152,153)$. Hence, for clinical trials evaluating the therapeutic response of metastatic disease that is predominantly osseous, several alternative response criteria have been created (154). Bone scintigraphy, CT, and serum prostate-specific antigen (PSA) studies all carry a risk of misdiagnosing a favorable tumor response as disease progression $(155,156)$; for example, some prostate cancer bone metastases are invisible on bone scintigraphy and CT and become visible only after a response to treatment occurs (i.e., the flare response phenomenon, also known as pseudoprogression) (156). MRI has not been shown to have reliable parameters that can differentiate tumor response to therapy from resistance. Second, monitoring tumor androgen metabolism clinically may provide insight into the emergence of resistant prostate cancer; although virtually all prostate cancer responds to androgen withdrawal initially, the disease often reemerges in an androgen-independent state (157).

\section{Clinical Studies with ${ }^{18} \mathrm{~F}-\mathrm{FDHT}$}

Larson et al. (158) described the pharmacokinetics and biodistribution of ${ }^{18} \mathrm{~F}-\mathrm{FDHT}$ in castrate prostate cancer patients with progressive disease (Fig. 10). On entering the bloodstream, ${ }^{18} \mathrm{~F}$-FDHT binds almost instantly to plasma proteins. By 10 min after intravenous injection, the majority of ${ }^{18} \mathrm{~F}$-FDHT has been converted to radiolabeled metabolites, found protein-bound in the circulation. ${ }^{18} \mathrm{~F}-\mathrm{FDHT}$ itself is extensively bound to SSBP (or sex hormone-binding globulin) $(159,160)$, and it is believed that this protein assists in the cellular uptake of steroids (131). In the study of Larson et al. (158), tumor ${ }^{18} \mathrm{~F}$-FDHT uptake was rapid, with prolonged retention; this activity provided good visualization of bony and soft-tissue tumor deposits, including a biopsy-confirmed, androgen receptor-positive prostate bed recurrence. The lead author of that article reports that ongoing clinical research has shown frequent discordance between ${ }^{18}$ F-FDG uptake and ${ }^{18}$ F-FDHT uptake in tumors (Steven M. Larson, oral communication, 2009). The biologic and clinical significance
A

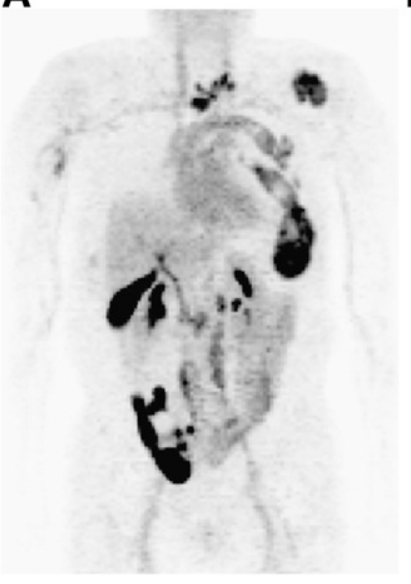

B

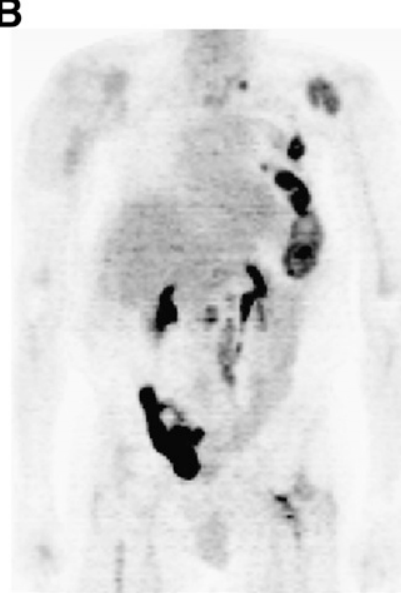

FIGURE 10. ${ }^{18} \mathrm{~F}-\mathrm{FDHT}$ (A) and ${ }^{18} \mathrm{~F}-\mathrm{FDG}(\mathrm{B})$ scans displayed in maximum-intensity-projection format. This figure demonstrates the contrasting metabolism of the 2 tracers in a patient with metastatic prostate cancer. (Reprinted with permission of (158).) 
of this discordance has not yet been determined; the observation invites speculation that these imaging phenotypes represent tumors with different behaviors and hormone responsiveness characteristics (161-164).

The preliminary clinical data of Larson et al. seem to support the notion suggested by preclinical research $(159,160)$ that ${ }^{18} \mathrm{~F}$-FDHT PET could be used to tailor the dosage and schedule of exogenous testosterone for individual patients to maintain the saturation of tumor androgen receptors. This idea was supported by the results of a larger response study by Dehdashti et al. (165), in which ${ }^{18}$ F-FDHT uptake was compared before and after treatment with flutamide, an androgen receptor antagonist; ${ }^{18} \mathrm{~F}$-FDHT uptake decreased significantly, consistent with various degrees of tumor androgen receptor saturation. That same study revealed an association between high PSA levels and positive ${ }^{18}$ F-FDHT scan results $(P=0.006)$ (165). What remains to be reported is whether various degrees of target saturation correlate with the tumor response. If greater saturation were found to correlate with a better response, then the argument for pursuing an ${ }^{18} \mathrm{~F}$-FDHT-based dose titration trial with an androgen receptor blocker would be compelling.

\section{FUTURE ADVANCES}

${ }^{11} \mathrm{C}$-Labeled Therapeutic Drugs

The clinical use of ${ }^{11} \mathrm{C}$-labeled PET tracers for clinical oncologic imaging is increasing significantly. It is conceivable that ${ }^{11} \mathrm{C}$ will also be incorporated into therapeutic drugs now under development. Such combinations will allow noninvasive direct monitoring of the effectiveness of these agents and will lead to a true understanding of their mechanisms. Moreover, they will allow monitoring of the effectiveness of a given formulation for the delivery of an agent. As a result, it will be possible to obtain a substantially more detailed understanding of the biology of a tumor in a given patient.

\section{${ }^{11} \mathrm{C}-$ Choline PET}

Given that the upregulation of choline kinase is often associated with cancer, a strong rationale exists for using ${ }^{11} \mathrm{C}$-choline in oncology. ${ }^{11} \mathrm{C}$-choline has been reported to be a new agent for PET of brain tumors and other cancers (166-168). In particular, ${ }^{11} \mathrm{C}$-choline PET has been shown to provide clear images of the pelvic region and of prostate carcinoma and pelvic lymph node metastasis (169-174). It has also been shown to have sensitivity and accuracy for the preoperative staging of prostate cancer in pelvic lymph nodes $(172,175)$. In 2003, de Jong et al. presented data on the use of ${ }^{11} \mathrm{C}$-choline PET for evaluation after the treatment of localized prostate cancer; the site of recurrence was detected correctly in $78 \%$ of the patients after externalbeam radiotherapy and in $38 \%$ of the patients after radical prostatectomy (176). Given the data already collected on the use of ${ }^{11} \mathrm{C}$-choline ( $~ 90$ publications), further study of the use of this agent for monitoring therapy is warranted.
$1-{ }^{11} \mathrm{C}$-Acetate PET

$1-{ }^{11} \mathrm{C}$-acetate has been extensively investigated as an imaging agent for prostate cancer and its metastases (177181). The most recent work has demonstrated $1{ }^{11} \mathrm{C}$-acetate to be useful for detecting recurrent prostate cancer at PSA relapse in many cases $(177,179,180,182)$. Direct comparisons have shown that $1-{ }^{11} \mathrm{C}$-acetate PET has greater sensitivity for detection than does ${ }^{18}$ F-FDG PET $(178,183)$. Recent findings of Vavere et al. suggested that $1-{ }^{11} \mathrm{C}$-acetate uptake is related to fatty acid synthase (FAS) expression in tumors (184). These findings suggest the possibility of using $1-{ }^{11} \mathrm{C}$-acetate as a biomarker for more effective treatments for prostate cancer patients and possibly others, because FAS expression has been shown to be linked to a poor prognosis in other cancers as well. Moreover, because FAS inhibitors are being developed as antitumor agents, this technology also provides a unique opportunity to monitor the effectiveness and the validation of new anticancer FAS inhibitors for translation into a clinical setting.

\section{Angiogenesis (Integrins)}

Cancer specialists are calling for clinical assays of tumor blood vessels that can guide the use of vascular targeted therapies by optimizing dose selection and identifying drug resistance, such as that which occurs with angiogenesis inhibitors. For PET of angiogenesis, 2 imaging agents have entered clinical trials: ${ }^{18} \mathrm{~F}$-galacto-RGD $(185,186)$ and ${ }^{18} \mathrm{~F}$ AH111 (187). Both tracers target the integrin molecule $\alpha v \beta 3$ and have various affinities for other $\alpha$ - and $\beta$-heterodimers. To date, no clinical data have been published regarding the use of these tracers in evaluating the tumor response to therapy.

\section{Herceptin}

Resistance to endocrine therapy in breast cancer often involves the overexpression of HER2 (127). Clinical trials with $\mathrm{F}\left(\mathrm{ab}^{\prime}\right)_{2}$-trastuzumab, an anti-HER2 antibody fragment dimer radiolabeled for PET, are ongoing (188).

\section{CONCLUSION}

This article has discussed progress in clinical PET research with new PET tracers for evaluating the tumor response at the level of biomolecular therapeutic targets and examining therapeutically relevant phenotypes of cellular biology and the tumor tissue microenvironment. Building on the success of ${ }^{18}$ F-FDG PET and a worldwide PET infrastructure, both firmly established and continually growing, a revolution is occurring in the detection of the tumor response to therapy. In the coming decade, cancer care specialists can look forward to a wave of noninvasive molecular probes other than ${ }^{18} \mathrm{~F}$-FDG for predicting and characterizing the tumor response to therapy in new ways that are more specific to the therapeutic regimens used. These clinical PET tools should improve therapeutic planning and response assessment and should lead to improved patient outcomes. 


\section{ACKNOWLEDGMENTS}

Financial assistance for this study was provided by an R25T Molecular Imaging Grant from the National Cancer Institute (R25-CA96945). The authors acknowledge Ada Muellner for careful editing of the article.

\section{REFERENCES}

1. Seidlin S, Marinelli L, Oshry E. Radioactive iodine therapy: effect on functioning metastases of adenocarcinoma of the thyroid. JAMA. 1946;132: 838-847.

2. Dunn JT, Dunn AD. Update on intrathyroidal iodine metabolism. Thyroid. 2001;11:407-414.

3. Robbins RJ, Wan Q, Grewal RK, et al. Real-time prognosis for metastatic thyroid carcinoma based on 2-[ $\left.{ }^{18} \mathrm{~F}\right]$ fluoro-2-deoxy-D-glucose-positron emission tomography scanning. J Clin Endocrinol Metab. 2006;91:498-505.

4. Hadj-Djilani NL, Lebtahi NE, Delaloye AB, Laurini R, Beck D. Diagnosis and follow-up of neuroblastoma by means of iodine-123 metaiodobenzylguanidine scintigraphy and bone scan, and the influence of histology. Eur J Nucl Med. 1995;22:322-329.

5. Lastoria S, Maurea S, Caraco C, et al. Iodine-131 metaiodobenzylguanidine scintigraphy for localization of lesions in children with neuroblastoma: comparison with computed tomography and ultrasonography. Eur J Nucl Med. 1993;20: 1161-1167.

6. Parisi MT, Greene MK, Dykes TM, Moraldo TV, Sandler ED, Hattner RS. Efficacy of metaiodobenzylguanidine as a scintigraphic agent for the detection of neuroblastoma. Invest Radiol. 1992;27:768-773.

7. Giammarile F, Lumbroso J, Ricard M, et al. Radioiodinated metaiodobenzylguanidine in neuroblastoma: influence of high dose on tumour site detection. Eur J Nucl Med. 1995;22:1180-1183.

8. Maurea S, Lastoria S, Caraco C, et al. Iodine-131-MIBG imaging to monitor chemotherapy response in advanced neuroblastoma: comparison with laboratory analysis. J Nucl Med. 1994;35:1429-1435.

9. Schmidt M, Simon T, Hero B, Schicha H, Berthold F. The prognostic impact of functional imaging with ${ }^{123} \mathrm{I}-\mathrm{mIBG}$ in patients with stage 4 neuroblastoma $>1$ year of age on a high-risk treatment protocol: results of the German Neuroblastoma Trial NB97. Eur J Cancer. 2008;44:1552-1558.

10. Katzenstein HM, Cohn SL, Shore RM, et al. Scintigraphic response by ${ }^{123}$ Imetaiodobenzylguanidine scan correlates with event-free survival in high-risk neuroblastoma. J Clin Oncol. 2004;22:3909-3915.

11. Matthay KK, Edeline V, Lumbroso J, et al. Correlation of early metastatic response by ${ }^{123}$ I-metaiodobenzylguanidine scintigraphy with overall response and event-free survival in stage IV neuroblastoma. J Clin Oncol. 2003;21: 2486-2491.

12. Lamberts SW, Bakker WH, Reubi JC, Krenning EP. Somatostatin-receptor imaging in the localization of endocrine tumors. N Engl J Med. 1990;323: 1246-1249.

13. Lamberts SW, Hofland LJ, van Koetsveld PM, et al. Parallel in vivo and in vitro detection of functional somatostatin receptors in human endocrine pancreatic tumors: consequences with regard to diagnosis, localization, and therapy. J Clin Endocrinol Metab. 1990;71:566-574.

14. Blankenberg FG. In vivo detection of apoptosis. J Nucl Med. 2008; 49(suppl):81S-95S.

15. Boersma HH, Liem IH, Kemerink GJ, et al. Comparison between human pharmacokinetics and imaging properties of two conjugation methods for 99mTc-annexin A5. Br J Radiol. 2003;76:553-560.

16. Bading JR, Shields AF. Imaging of cell proliferation: status and prospects. $J$ Nucl Med. 2008;49(suppl):64S-80S.

17. Schwartz JL, Tamura Y, Jordan R, Grierson JR, Krohn KA. Monitoring tumor cell proliferation by targeting DNA synthetic processes with thymidine and thymidine analogs. J Nucl Med. 2003;44:2027-2032.

18. Tehrani OS, Douglas KA, Lawhorn-Crews JM, Shields AF. Tracking cellular stress with labeled FMAU reflects changes in mitochondrial TK2. Eur J Nucl Med Mol Imaging. 2008;35:1480-1488.

19. Bading JR, Shahinian AH, Vail A, et al. Pharmacokinetics of the thymidine analog 2'-fluoro-5-methyl-1-beta-D-arabinofuranosyluracil (FMAU) in tumorbearing rats. Nucl Med Biol. 2004;31:407-418.

20. O'Neill KL, Hoper M, Odling-Smee GW. Can thymidine kinase levels in breast tumors predict disease recurrence? J Natl Cancer Inst. 1992;84:1825-1828.

21. Ellims PH, Gan TE, Van der Weyden MB. Thymidine kinase isoenzymes in chronic lymphocytic leukaemia. Br J Haematol. 1981;49:479-481.
22. Haveman J, Sigmond J, van Bree C, Franken NA, Koedooder C, Peters GJ. Time course of enhanced activity of deoxycytidine kinase and thymidine kinase 1 and 2 in cultured human squamous lung carcinoma cells, SW-1573, induced by gamma-irradiation. Oncol Rep. 2006;16:901-905.

23. Han T, Fernandez M, Sarkar M, Agarwal RP. 2', 3'-Dideoxycytidine represses thymidine kinases 1 and 2 expression in T-lymphoid cells. Life Sci. 2004; 74:835-842.

24. Han T, Fernandez M, Sarkar M, Agarwal RP. Arabinosylcytosine downregulates thymidine kinase and induces cross-resistance to zidovudine in T-lymphoid cells. Biochem Biophys Res Commun. 2003;307:564-568.

25. Atkinson DM, Clarke MJ, Mladek AC, et al. Using fluorodeoxythymidine to monitor anti-EGFR inhibitor therapy in squamous cell carcinoma xenografts. Head Neck. 2008;30:790-799.

26. Dittmann H, Dohmen B, Kehlbach R, et al. Early changes in $\left[{ }^{18}\right.$ F $]$ FLT uptake after chemotherapy: an experimental study. Eur J Nucl Med Mol Imaging. 2002;29:1462-1469.

27. Monazzam A, Josephsson R, Blomqvist C, Carlsson J, Langstrom B, Bergstrom M. Application of the multicellular tumour spheroid model to screen PET tracers for analysis of early response of chemotherapy in breast cancer. Breast Cancer Res. 2007;9:R45

28. Direcks WG, Berndsen SC, Proost N, et al. $\left[{ }^{18} \mathrm{~F}\right]$ FDG and $\left[{ }^{18} \mathrm{~F}\right] \mathrm{FLT}$ uptake in human breast cancer cells in relation to the effects of chemotherapy: an in vitro study. Br J Cancer. 2008;99:481-487.

29. van Waarde A, Been LB, Ishiwata K, Dierckx RA, Elsinga PH. Early response of sigma-receptor ligands and metabolic PET tracers to 3 forms of chemotherapy: an in vitro study in glioma cells. J Nucl Med. 2006;47:1538-1545.

30. Bergstrom M, Monazzam A, Razifar P, Ide S, Josephsson R, Langstrom B. Modeling spheroid growth, PET tracer uptake, and treatment effects of the Hsp90 inhibitor NVP-AUY922. J Nucl Med. 2008;49:1204-1210.

31. Perumal M, Pillai RG, Barthel $\mathrm{H}$, et al. Redistribution of nucleoside transporters to the cell membrane provides a novel approach for imaging thymidylate synthase inhibition by positron emission tomography. Cancer Res. 2006;66:8558-8564.

32. Wei LH, Su H, Hildebrandt IJ, Phelps ME, Czernin J, Weber WA. Changes in tumor metabolism as readout for mammalian target of rapamycin kinase inhibition by rapamycin in glioblastoma. Clin Cancer Res. 2008;14:3416-3426.

33. Schwartz JL, Tamura Y, Jordan R, Grierson JR, Krohn KA. Effect of p53 activation on cell growth, thymidine kinase-1 activity, and $3^{\prime}$-deoxy-3'fluorothymidine uptake. Nucl Med Biol. 2004;31:419-423.

34. Solit DB, Santos E, Pratilas CA, et al. $3^{\prime}$-Deoxy- $3^{\prime}-\left[{ }^{18} \mathrm{~F}\right]$ fluorothymidine positron emission tomography is a sensitive method for imaging the response of BRAF-dependent tumors to MEK inhibition. Cancer Res. 2007;67:1146311469.

35. Apisarnthanarax S, Alauddin MM, Mourtada F, et al. Early detection of chemoradioresponse in esophageal carcinoma by $33^{\prime}$-deoxy $-3^{\prime}-{ }^{3} \mathrm{H}$-fluorothymidine using preclinical tumor models. Clin Cancer Res. 2006;12:4590-4597.

36. Leyton J, Alao JP, Da Costa M, et al. In vivo biological activity of the histone deacetylase inhibitor LAQ824 is detectable with $3^{\prime}$-deoxy- $3^{\prime}-\left[{ }^{18} \mathrm{~F}\right]$ fluorothymidine positron emission tomography. Cancer Res. 2006;66:7621-7629.

37. Barthel H, Cleij MC, Collingridge DR, et al. $3^{\prime}$-Deoxy- $3^{\prime}-\left[{ }^{18} \mathrm{~F}\right]$ fluorothymidine as a new marker for monitoring tumor response to antiproliferative therapy in vivo with positron emission tomography. Cancer Res. 2003;63:3791-3798.

38. Pillai RG, Forster M, Perumal M, et al. Imaging pharmacodynamics of the alpha-folate receptor-targeted thymidylate synthase inhibitor BGC 945. Cancer Res. 2008;68:3827-3834.

39. Pan MH, Huang SC, Liao YP, et al. FLT-PET imaging of radiation responses in murine tumors. Mol Imaging Biol. 2008;10:325-334.

40. Yang YJ, Ryu JS, Kim SY, et al. Use of $3^{\prime}$-deoxy- $3^{\prime}-\left[{ }^{18} \mathrm{~F}\right]$ fluorothymidine PET to monitor early responses to radiation therapy in murine SCCVII tumors. Eur J Nucl Med Mol Imaging. 2006;33:412-419.

41. Leyton J, Latigo JR, Perumal M, Dhaliwal H, He Q, Aboagye EO. Early detection of tumor response to chemotherapy by $3^{\prime}$-deoxy- $3^{\prime}-\left[{ }^{18} \mathrm{~F}\right]$ fluorothymidine positron emission tomography: the effect of cisplatin on a fibrosarcoma tumor model in vivo. Cancer Res. 2005;65:4202-4210.

42. Waldherr C, Mellinghoff IK, Tran C, et al. Monitoring antiproliferative responses to kinase inhibitor therapy in mice with $3^{\prime}$-deoxy- $3^{\prime}-{ }^{18} \mathrm{~F}$-fluorothymidine PET. J Nucl Med. 2005;46:114-120.

43. Sugiyama M, Sakahara H, Sato K, et al. Evaluation of $3^{\prime}$-deoxy- $3^{\prime}-{ }^{18} \mathrm{~F}-$ fluorothymidine for monitoring tumor response to radiotherapy and photodynamic therapy in mice. $J$ Nucl Med. 2004;45:1754-1758.

44. Cheon GJ, Chung HK, Choi JA, et al. Cellular metabolic responses of PET radiotracers to ${ }^{188} \mathrm{Re}$ radiation in an MCF7 cell line containing dominantnegative mutant p53. Nucl Med Biol. 2007;34:425-432. 
45. Buck AK, Kratochwil C, Glatting G, et al. Early assessment of therapy response in malignant lymphoma with the thymidine analogue $\left[{ }^{18} \mathrm{~F}\right] \mathrm{FLT}$. Eur $J$ Nucl Med Mol Imaging. 2007;34:1775-1782.

46. Molthoff CF, Klabbers BM, Berkhof J, et al. Monitoring response to radiotherapy in human squamous cell cancer bearing nude mice: comparison of $2^{\prime}$ deoxy- $2^{\prime}-\left[{ }^{18} \mathrm{~F}\right]$ fluoro-D-glucose (FDG) and $3^{\prime}-\left[{ }^{18} \mathrm{~F}\right]$ fluoro- $3^{\prime}$-deoxythymidine (FLT). Mol Imaging Biol. 2007;9:340-347.

47. Kasper B, Egerer G, Gronkowski M, et al. Functional diagnosis of residual lymphomas after radiochemotherapy with positron emission tomography comparing FDG- and FLT-PET. Leuk Lymphoma. 2007;48:746-753.

48. Smyczek-Gargya B, Fersis N, Dittmann H, et al. PET with $\left[{ }^{18} \mathrm{~F}\right]$ fluorothymidine for imaging of primary breast cancer: a pilot study. Eur J Nucl Med Mol Imaging. 2004;31:720-724.

49. Dittmann H, Dohmen BM, Paulsen F, et al. $\left[{ }^{18}\right.$ F $]$ FLT PET for diagnosis and staging of thoracic tumours. Eur J Nucl Med Mol Imaging. 2003;30:1407-1412.

50. Shields AF, Lawhorn-Crews JM, Briston DA, et al. Analysis and reproducibility of $3^{\prime}$-deoxy- $3^{\prime}-\left[{ }^{18} \mathrm{~F}\right]$ fluorothymidine positron emission tomography imaging in patients with non-small cell lung cancer. Clin Cancer Res. 2008;14:4463-4468.

51. Muzi M, Mankoff DA, Grierson JR, Wells JM, Vesselle H, Krohn KA. Kinetic modeling of $3^{\prime}$-deoxy-3'-fluorothymidine in somatic tumors: mathematical studies. J Nucl Med. 2005;46:371-380.

52. Muzi M, Spence AM, O'Sullivan F, et al. Kinetic analysis of $3^{\prime}$-deoxy- $3^{\prime}-{ }^{18}$ Ffluorothymidine in patients with gliomas. J Nucl Med. 2006;47:1612-1621.

53. Muzi M, Vesselle H, Grierson JR, et al. Kinetic analysis of $3^{\prime}$-deoxy-3'fluorothymidine PET studies: validation studies in patients with lung cancer. $J$ Nucl Med. 2005;46:274-282.

54. Schiepers C, Chen W, Dahlbom M, Cloughesy T, Hoh CK, Huang SC. ${ }^{18} \mathrm{~F}-$ fluorothymidine kinetics of malignant brain tumors. Eur J Nucl Med $\mathrm{Mol}$ Imaging. 2007;34:1003-1011.

55. Wieder HA, Geinitz H, Rosenberg R, et al. PET imaging with $\left[{ }^{18} \mathrm{~F}\right] 3^{\prime}$-deoxy-3' fluorothymidine for prediction of response to neoadjuvant treatment in patients with rectal cancer. Eur J Nucl Med Mol Imaging. 2007;34:878-883.

56. Guillem JG, Chessin DB, Cohen AM, et al. Long-term oncologic outcome following preoperative combined modality therapy and total mesorectal excision of locally advanced rectal cancer. Ann Surg. 2005;241:829-836.

57. Chen W, Delaloye S, Silverman DH, et al. Predicting treatment response of malignant gliomas to bevacizumab and irinotecan by imaging proliferation with $\left[{ }^{18} \mathrm{~F}\right]$ fluorothymidine positron emission tomography: a pilot study. J Clin Oncol. 2007;25:4714-4721.

58. Herrmann K, Wieder HA, Buck AK, et al. Early response assessment using $3^{\prime}$ deoxy- $3^{\prime}-\left[{ }^{18} \mathrm{~F}\right]$ fluorothymidine-positron emission tomography in high-grade non-Hodgkin's lymphoma. Clin Cancer Res. 2007;13:3552-3558.

59. Sun H, Sloan A, Mangner TJ, et al. Imaging DNA synthesis with $\left[{ }^{18} \mathrm{~F}\right] \mathrm{FMAU}$ and positron emission tomography in patients with cancer. Eur J Nucl Med Mol Imaging. 2005;32:15-22.

60. Tehrani OS, Muzik O, Heilbrun LK, et al. Tumor imaging using 1-(2'-deoxy$2{ }^{\prime}-{ }^{18}$ F-fluoro- $\beta$-D-arabinofuranosyl)thymine and PET. J Nucl Med. 2007;48: 1436-1441.

61. Brown JM. The hypoxic cell: a target for selective cancer therapy-Eighteenth Bruce F. Cain Memorial Award Lecture. Cancer Res. 1999;59:5863-5870.

62. Graeber TG, Osmanian C, Jacks T, et al. Hypoxia-mediated selection of cells with diminished apoptotic potential in solid tumours. Nature. 1996; 379:88-91.

63. Höckel M, Schlenger K, Aral B, Mitze M, Schäffer U, Vaupel P. Association between tumor hypoxia and malignant progression in advanced cancer of the uterine cervix. Cancer Res. 1996;56:4509-4515.

64. Shweiki D, Itin A, Soffer D, Keshet E. Vascular endothelial growth factor induced by hypoxia may mediate hypoxia-initiated angiogenesis. Nature. 1992;359:843-845.

65. Ballinger JR. Imaging hypoxia in tumors. Semin Nucl Med. 2001;31:321-329.

66. Tatum JL, Kelloff GJ, Gillies RJ, et al. Hypoxia: importance in tumor biology, noninvasive measurement by imaging, and value of its measurement in the management of cancer therapy. Int J Radiat Biol. 2006;82:699-757.

67. Zhang X, Melo T, Ballinger JR, Rauth AM. Studies of 99m Tc-BnAO (HL-91): a non-nitroaromatic compound for hypoxic cell detection. Int J Radiat Oncol Biol Phys. 1998;42:737-740.

68. Evans SM, Kachur AV, Shiue CY, et al. Noninvasive detection of tumor hypoxia using the 2-nitroimidazole [ ${ }^{18}$ F]EF1. J Nucl Med. 2000;41:327-336.

69. Cook GJ, Houston S, Barrington SF, Fogelman I. Technetium-99m-labeled HL91 to identify tumor hypoxia: correlation with fluorine-18-FDG. $\mathrm{J} \mathrm{Nucl}$ Med. 1998;39:99-103.

70. Piert M, Machulla HJ, Picchio M, et al. Hypoxia-specific tumor imaging with ${ }^{18}$ F-fluoroazomycin arabinoside. J Nucl Med. 2005;46:106-113.
71. Tatsumi M, Yutani K, Kusuoka H, Nishimura T. Technetium-99m HL91 uptake as a tumour hypoxia marker: relationship to tumour blood flow. Eur J Nucl Med. 1999;26:91-94.

72. Vavere AL, Lewis JS. Cu-ATSM: a radiopharmaceutical for the PET imaging of hypoxia. Dalton Trans. 2007;43:4893-4902.

73. Blower PJ, Castle TC, Cowley AR, et al. Structural trends in copper(II) bis(thiosemicarbazone) radiopharmaceuticals. Dalton Trans. 2003;23:44164425 .

74. Blower PJ, Dilworth JR, Maurer RI, Mullen GED, Reynolds CA, Zheng Y. Towards new transition metal-based hypoxic selective agents for therapy and imaging. J Inorg Biochem. 2001;85:15-22.

75. Burgman P, O’Donoghue JA, Lewis JS, Welch MJ, Humm JL, Ling CC. Cell line dependent differences in uptake and retention of the hypoxia selective nuclear imaging agent Cu-diacetyl-bis $\left(N^{4}\right.$-methylthiosemicarbazone) (CuATSM). Nucl Med Biol. 2005;32:623-630.

76. Cowley AR, Dilworth JR, Donnelly PS, White JM. Copper complexes of thiosemicarbazone-pyridylhydrazine (THYNIC) hybrid ligands: a new versatile potential bifunctional chelator for copper radiopharmaceuticals. Inorg Chem. 2006;45:496-498.

77. Dearling JLD, Lewis JS, Mullen GED, Rae MT, Zweit J, Blower PJ. Design of hypoxia-targeting radiopharmaceuticals: selective uptake of copper-64 complexes in hypoxic cells in vitro. Eur J Nucl Med. 1998;25:788-792.

78. Dearling JLJ, Lewis JS, Mullen GED, Welch MJ, Blower PJ. Copper bis(thiosemicarbazone) complexes as hypoxia imaging agents: structureactivity relationships. J Biol Inorg Chem. 2002;7:249-259.

79. Holland JP, Green JC, Dilworth JR. Probing the mechanism of hypoxia selectivity of copper bis(thiosemicarbazonato) complexes: DFT calculation of redox potentials and absolute acidities in solution. Dalton Trans. 2006;(6):783794.

80. Maurer RI, Blower PJ, Dilworth JR, Reynolds CA, Zheng Y, Mullen GED. Studies on the mechanism of hypoxic selectivity in copper bis(thiosemicarbazone) radiopharmaceuticals. J Med Chem. 2002;45:1420-1431.

81. Taniuchi H, Fujibayashi Y, Yonekura Y, Konishi J, Yokoyama A. Hyperfixation of copper-62-PTSM in rat brain after transient global ischemia. J Nucl Med. 1997;38:1130-1134.

82. Takahashi N, Fujibayashi Y, Yonekura Y, et al. Evaluation of ${ }^{62} \mathrm{Cu}$ labeled diacetyl-bis $\left(N^{4}\right.$-methylthiosemicarbazone) as a hypoxic tissue tracer in patients with lung cancer. Ann Nucl Med. 2000;14:323-328.

83. Dehdashti F, Grigsby PW, Lewis JS, Laforest R, Siegel BA, Welch MJ. Assessing tumor hypoxia in cervical cancer by positron emission tomography with ${ }^{60} \mathrm{Cu}$-ATSM. J Nucl Med. 2008;49:201-205.

84. Dehdashti F, Mintun MA, Lewis JS, et al. In vivo assessment of tumor hypoxia in lung cancer with ${ }^{60} \mathrm{Cu}$-ATSM. Eur J Nucl Med Mol Imaging. 2003;30:844850 .

85. Dietz DW, Dehdashti FD, Grigsby PW, et al. Tumor hypoxia detected by positron emission tomography with ${ }^{60} \mathrm{Cu}$-ATSM as a predictor of response and survival in patients undergoing neoadjuvant chemoradiotherapy for rectal carcinoma: a pilot study. Dis Colon Rectum. 2008;51:1641-1648.

86. Lewis JS, Laforest R, Dehdashti F, Grigsby PW, Welch MJ, Siegel BA. An imaging comparison of ${ }^{64} \mathrm{Cu}$-ATSM and ${ }^{60} \mathrm{Cu}$-ATSM in cancer of the uterine cervix. J Nucl Med. 2008;49:1177-1182.

87. Dehdashti F, Grigsby PW, Mintun MA, Lewis JS, Siegel BA, Welch MJ. Assessing tumor hypoxia in cervical cancer by positron emission tomography with ${ }^{60} \mathrm{Cu}$-ATSM: relationship to therapeutic response-a preliminary report. Int J Radiat Oncol Biol Phys. 2003;55:1233-1238.

88. Lewis JS, Welch MJ, Tang L. Workshop on the production, application and clinical translation of "non-standard" PET nuclides: a meeting report. $Q \mathrm{~J} \mathrm{Nucl}$ Med Mol Imaging. 2008;52:101-106.

89. Padhani AR, Krohn KA, Lewis JS, Alber M. Imaging oxygenation of human tumors. Eur Radiol. 2007;17:861-872.

90. Rajendran JG, Krohn KA. Imaging hypoxia and angiogenesis in tumors. Radiol Clin North Am. 2005;43:169-187.

91. Koh W-J, Rasey JS, Evans ML. Imaging of hypoxia in human tumors with [F-18]fluoromisonidazole. Int J Radiat Oncol Biol Phys. 1992;22:199-212.

92. Rasey JS, Wui-Jin K, Grierson JR, Grunbaum Z, Krohn KA. Radiolabeled fluoromisonidazole as an imaging agent for tumor hypoxia. Int J Radiat Oncol Biol Phys. 1989;17:985-991.

93. Rajendran JG, Wilson DC, Conrad EU, et al. $\left[{ }^{18} \mathrm{~F}\right] \mathrm{FMISO}$ and $\left[{ }^{18} \mathrm{~F}\right] \mathrm{FDG}$ PET imaging in soft tissue sarcomas: correlation of hypoxia, metabolism and VEGF expression. Eur J Nucl Med Mol Imaging. 2003;30:695-704.

94. Rasey JS, Koh WJ, Evans ML, et al. Quantifying regional hypoxia in human tumors with positron emission tomography of $\left[{ }^{18} \mathrm{~F}\right]$ fluoromisonidazole: a pretherapy study of 37 patients. Int J Radiat Oncol Biol Phys. 1996;36:417428 . 
95. Rasey JS, Nelson NJ, Chin LK, Evans ML, Grunbaum Z. Characteristics of the binding of labeled fluoromisonidazole in cells in vitro. Radiat Res. 1990; 122:301-308.

96. Rajendran JG, Schwartz DL, O'Sullivan J, et al. Tumor hypoxia imaging with [F-18]fluoromisonidazole positron emission tomography in head and neck cancer. Clin Cancer Res. 2006;12:5435-5441.

97. Spence AM, Muzi M, Swanson KR, et al. Regional hypoxia in glioblastoma multiforme quantified with $\left[{ }^{18} \mathrm{~F}\right]$ fluoromisonidazole positron emission tomography before radiotherapy: correlation with time to progression and survival. Clin Cancer Res. 2008;14:2623-2630.

98. Nehmeh SA, Lee NY, Schroder H, et al. Reproducibility of intratumor distribution of ${ }^{18} \mathrm{~F}$-fluoromisonidazole in head and neck cancer. Int $J$ Radiat Oncol Biol Phys. 2008;70:235-242.

99. Rischin D, Hicks RJ, Fisher R, et al. Prognostic significance of $\left[{ }^{18} \mathrm{~F}\right]$ misonidazole positron emission tomography-detected tumor hypoxia in patients with advanced head and neck cancer randomly assigned to chemoradiation with or without tirapazamine: a substudy of Trans-Tasman Radiation Oncology Group Study 98.02. $J$ Clin Oncol. 2006;24:2098-2104.

100. Nunn A, Linder K, Strauss HW. Nitroimidazoles and imaging hypoxia. Eur J Nucl Med. 1995;22:265-280.

101. Rajendran JG, Mankoff DA, O'Sullivan F, et al. Hypoxia and glucose metabolism in malignant tumors: evaluation by $\left[{ }^{18} \mathrm{~F}\right]$ fluoromisonidazole and $\left[{ }^{18} \mathrm{~F}\right]$ fluorodeoxyglucose positron emission tomography imaging. Clin Cancer Res. 2004;10:2245-2252.

102. Cherk MH, Foo SS, Poon AM, et al. Lack of correlation of hypoxic cell fraction and angiogenesis with glucose metabolic rate in non-small cell lung cancer assessed by ${ }^{18}$ F-fluoromisonidazole and ${ }^{18}$ F-FDG PET. J Nucl Med. 2006;47: 1921-1926.

103. Singhal T, Narayan TK, Jain V, Mukherjee J, Mantil J. ${ }^{11} \mathrm{C}$-L-methionine positron emission tomography in the clinical management of cerebral gliomas. Mol Imaging Biol. 2008;10:1-18.

104. Galldiks N, Kracht LW, Burghaus L, et al. Use of ${ }^{11} \mathrm{C}-$ methionine PET to monitor the effects of temozolomide chemotherapy in malignant gliomas. Eur $J$ Nucl Med Mol Imaging. 2006;33:516-524.

105. Lee IH, Piert M, Gomez-Hassan D, et al. Association of ${ }^{11} \mathrm{C}$-methionine PET uptake with site of failure after concurrent temozolomide and radiation for primary glioblastoma multiforme. Int J Radiat Oncol Biol Phys. 2009;73:479_ 485.

106. Terakawa Y, Tsuyuguchi N, Iwai $\mathrm{Y}$, et al. Diagnostic accuracy of ${ }^{11} \mathrm{C}$ methionine PET for differentiation of recurrent brain tumors from radiation necrosis after radiotherapy. J Nucl Med. 2008;49:694-699.

107. Ogawa T, Miura S, Murakami M, et al. Quantitative evaluation of neutral amino acid transport in cerebral gliomas using positron emission tomography and fluorine-18 fluorophenylalanine. Eur J Nucl Med. 1996;23:889-895.

108. Wienhard K, Herholz K, Coenen HH, et al. Increased amino acid transport into brain tumors measured by PET of $\mathrm{L}-\left(2-{ }^{18} \mathrm{~F}\right)$ fluorotyrosine. J Nucl Med. 1991;32:1338-1346.

109. Wester HJ, Herz M, Weber W, et al. Synthesis and radiopharmacology of $O-\left(2-\left[{ }^{18} \mathrm{~F}\right]\right.$ fluoroethyl)-L-tyrosine for tumor imaging. J Nucl Med. 1999;40: 205-212.

110. Shoup TM, Olson J, Hoffman JM, et al. Synthesis and evaluation of $\left[{ }^{18} \mathrm{~F}\right] 1-$ amino-3-fluorocyclobutane-1-carboxylic acid to image brain tumors. $\mathrm{J} \mathrm{Nucl}$ Med. 1999;40:331-338.

111. McConathy J, Voll RJ, Yu W, Crowe RJ, Goodman MM. Improved synthesis of anti- $\left[{ }^{18} \mathrm{~F}\right] \mathrm{FACBC}$ : improved preparation of labeling precursor and automated radiosynthesis. Appl Radiat Isot. 2003;58:657-666.

112. Weber WA, Wester HJ, Grosu AL, et al. $O$ - $\left(2-\left[{ }^{18} \mathrm{~F}\right]\right.$ fluoroethyl $)$-L-tyrosine and $\mathrm{L}-\left[\right.$ methyl- $\left.{ }^{11} \mathrm{C}\right]$ methionine uptake in brain tumours: initial results of a comparative study. Eur J Nucl Med. 2000;27:542-549.

113. Pauleit D, Stoffels G, Schaden W, et al. PET with $O-\left(2-{ }^{18} \mathrm{~F}\right.$-fluoroethyl $)-\mathrm{L}-$ tyrosine in peripheral tumors: first clinical results. J Nucl Med. 2005;46:411416.

114. Pauleit D, Zimmermann A, Stoffels G, et al. ${ }^{18}$ F-FET PET compared with ${ }^{18} \mathrm{~F}$ FDG PET and CT in patients with head and neck cancer. J Nucl Med. 2006;47:256-261.

115. Nye JA, Schuster DM, Yu W, Camp VM, Goodman MM, Votaw JR. Biodistribution and radiation dosimetry of the synthetic nonmetabolized amino acid analogue anti- ${ }^{18} \mathrm{~F}-\mathrm{FACBC}$ in humans. $\mathrm{J} \mathrm{Nucl} \mathrm{Med.} \mathrm{2007;48:1017-1020.}$

116. Oka S, Hattori R, Kurosaki F, et al. A preliminary study of anti-1-amino-3- ${ }^{18} \mathrm{~F}-$ fluorocyclobutyl-1-carboxylic acid for the detection of prostate cancer. $J$ Nucl Med. 2007;48:46-55.

117. Schuster DM, Votaw JR, Nieh PT, et al. Initial experience with the radiotracer anti-1-amino-3- ${ }^{18}$ F-fluorocyclobutane-1-carboxylic acid with PET/CT in prostate carcinoma. J Nucl Med. 2007;48:56-63.
118. Tsujikawa T, Yoshida Y, Mori T, et al. Uterine tumors: pathophysiologic imaging with 16alpha- $\left[{ }^{18} \mathrm{~F}\right]$ fluoro-17beta-estradiol and ${ }^{18} \mathrm{~F}$ fluorodeoxyglucose PET-initial experience. Radiology. 2008;248:599-605.

119. Yoshida Y, Kurokawa T, Sawamura Y, et al. The positron emission tomography with F-18 17beta-estradiol has the potential to benefit diagnosis and treatment of endometrial cancer. Gynecol Oncol. 2007;104:764-766.

120. Moresco RM, Scheithauer BW, Lucignani G, et al. Oestrogen receptors in meningiomas: a correlative PET and immunohistochemical study. Nucl Med Commun. 1997;18:606-615.

121. Dunnwald LK, Rossing MA, Li CI. Hormone receptor status, tumor characteristics, and prognosis: a prospective cohort of breast cancer patients. Breast Cancer Res. 2007;9:R6.

122. Goldhirsch A, Glick JH, Gelber RD, et al. Meeting Highlights: International Expert Consensus on the Primary Therapy of Early Breast Cancer 2005. Ann Oncol. 2005;16:1569-1583.

123. Fernandez-Morales LA, Segui MA, Andreu X, et al. Analysis of the pathologic response to primary chemotherapy in patients with locally advanced breast cancer grouped according to estrogen receptor, progesterone receptor, and HER2 status. Clin Breast Cancer. 2007;7:559-564.

124. Steeg PS. Heterogeneity of drug target expression among metastatic lesions: lessons from a breast cancer autopsy program. Clin Cancer Res. 2008;14:36433645 .

125. Kumar P, Mercer J, Doerkson C, Tonkin K, McEwan AJ. Clinical production, stability studies and PET imaging with 16-alpha- $\left[{ }^{18} \mathrm{~F}\right]$ fluoroestradiol $\left(\left[{ }^{18} \mathrm{~F}\right] \mathrm{FES}\right)$ in ER positive breast cancer patients. J Pharm Pharm Sci. 2007;10:256s-265s.

126. Kuukasjarvi T, Kononen J, Helin H, Holli K, Isola J. Loss of estrogen receptor in recurrent breast cancer is associated with poor response to endocrine therapy. J Clin Oncol. 1996;14:2584-2589.

127. Zilli M, Grassadonia A, Tinari N, et al. Molecular mechanisms of endocrine resistance and their implication in the therapy of breast cancer. Biochim Biophys Acta. 2009;1795:62-81.

128. Harris L, Fritsche H, Mennel R, et al. American Society of Clinical Oncology 2007 update of recommendations for the use of tumor markers in breast cancer. J Clin Oncol. 2007;25:5287-5312.

129. McElvany KD, Katzenellenbogen JA, Shafer KE, et al. $16 \alpha-\left[{ }^{77} \mathrm{Br}\right]$ bromoestradiol: dosimetry and preliminary clinical studies. J Nucl Med. 1982;23:425-430.

130. Mankoff DA, Tewson TJ, Eary JF. Analysis of blood clearance and labeled metabolites for the estrogen receptor tracer [F-18]-16 alpha-fluoroestradiol (FES). Nucl Med Biol. 1997;24:341-348.

131. Tewson TJ, Mankoff DA, Peterson LM, Woo I, Petra P. Interactions of 16alpha$\left[{ }^{18} \mathrm{~F}\right]$-fluoroestradiol (FES) with sex steroid binding protein (SBP). Nucl Med Biol. 1999;26:905-913.

132. Peterson LM, Mankoff DA, Lawton T, et al. Quantitative imaging of estrogen receptor expression in breast cancer with PET and ${ }^{18}$ F-fluoroestradiol. $J$ Nucl Med. 2008;49:367-374.

133. Dehdashti F, Mortimer JE, Siegel BA, et al. Positron tomographic assessment of estrogen receptors in breast cancer: comparison with FDG-PET and in vitro receptor assays. J Nucl Med. 1995;36:1766-1774.

134. Mintun MA, Welch MJ, Siegel BA, et al. Breast cancer: PET imaging of estrogen receptors. Radiology. 1988;169:45-48.

135. Regan MM, Viale G, Mastropasqua MG, et al. Re-evaluating adjuvant breast cancer trials: assessing hormone receptor status by immunohistochemical versus extraction assays. J Natl Cancer Inst. 2006;98:1571-1581.

136. Kiesewetter DO, Kilbourn MR, Landvatter SW, Heiman DF, Katzenellenbogen JA, Welch MJ. Preparation of four fluorine-18-labeled estrogens and their selective uptakes in target tissues of immature rats. J Nucl Med. 1984;25:12121221.

137. Pomper MG, VanBrocklin H, Thieme AM, et al. 11 Beta-methoxy-, 11 betaethyl- and 17 alpha-ethynyl-substituted 16 alpha-fluoroestradiols: receptorbased imaging agents with enhanced uptake efficiency and selectivity. $J$ Med Chem. 1990;33:3143-3155.

138. Yoo J, Dence CS, Sharp TL, Katzenellenbogen JA, Welch MJ. Synthesis of an estrogen receptor beta-selective radioligand: $5-\left[{ }^{18} \mathrm{~F}\right]$ fluoro- $(2 R, 3 S)-2,3-b i s(4-$ hydroxyphenyl)pentanenitrile and comparison of in vivo distribution with 16alpha- $\left[{ }^{18}\right.$ F]fluoro-17beta-estradiol. J Med Chem. 2005;48:6366-6378.

139. Katzenellenbogen JA, Mathias CJ, Vanbrocklin HF, Brodack JW, Welch MJ. Titration of the in vivo uptake of 16 [alpha]-[ $\left.{ }^{18} \mathrm{~F}\right]$ fluoroestradiol by target tissues in the rat: competition by tamoxifen, and implications for quantitating estrogen receptors in vivo and the use of animal models in receptor-binding radiopharmaceutical development. Nucl Med Biol. 1993;20:735-745.

140. Dehdashti F, Mortimer JE, Trinkaus K, et al. PET-based estradiol challenge as a predictive biomarker of response to endocrine therapy in women with estrogen-receptor-positive breast cancer. Breast Cancer Res Treat. 2009; 113:509-517. 
141. McGuire AH, Dehdashti F, Siegel BA, et al. Positron tomographic assessment of $16 \alpha-\left[{ }^{18} \mathrm{~F}\right]$ fluoro-17ß-estradiol uptake in metastatic breast carcinoma. $\mathrm{J} \mathrm{Nucl}$ Med. 1991;32:1526-1531.

142. Linden HM, Stekhova SA, Link JM, et al. Quantitative fluoroestradiol positron emission tomography imaging predicts response to endocrine treatment in breast cancer. J Clin Oncol. 2006;24:2793-2799.

143. Mortimer JE, Dehdashti F, Siegel BA, Trinkaus K, Katzenellenbogen JA, Welch MJ. Metabolic flare: indicator of hormone responsiveness in advanced breast cancer. J Clin Oncol. 2001;19:2797-2803.

144. Dehdashti F, Flanagan FL, Mortimer JE, Katzenellenbogen JA, Welch MJ, Siegel BA. Positron emission tomographic assessment of "metabolic flare" to predict response of metastatic breast cancer to antiestrogen therapy. Eur J Nucl Med. 1999;26:51-56.

145. Mortimer JE, Dehdashti F, Siegel BA, Katzenellenbogen JA, Fracasso P, Welch MJ. Positron emission tomography with 2-[ $\left.{ }^{18} \mathrm{~F}\right]$ fluoro-2-deoxy-D-glucose and 16alpha$\left[{ }^{18} \mathrm{~F}\right]$ fluoro-17beta-estradiol in breast cancer: correlation with estrogen receptor status and response to systemic therapy. Clin Cancer Res. 1996;2:933-939.

146. Hawkin RA, Arends MJ, Ritchie AA, Langdon S, Miller WR. Tamoxifen increases apoptosis but does not influence markers of proliferation in an MCF-7 xenograft model of breast cancer. Breast. 2000;9:96-106.

147. Clark JH, Peck EJ Jr, Anderson JN. Oestrogen receptors and antagonism of steroid hormone action. Nature. 1974;251:446-448.

148. Horwitz KB, McGuire WL. Nuclear mechanisms of estrogen action: effects of estradiol and anti-estrogens on estrogen receptors and nuclear receptor processing. J Biol Chem. 1978;253:8185-8191.

149. Tormey DC, Simon RM, Lippman ME, Bull JM, Myers CE. Evaluation of tamoxifen dose in advanced breast cancer: a progress report. Cancer Treat Rep. 1976;60:1451-1459.

150. Fabian C, Sternson L, Barnett M. Clinical pharmacology of tamoxifen in patients with breast cancer: comparison of traditional and loading dose schedules. Cancer Treat Rep. 1980;64:765-773.

151. Sabnis GJ, Macedo LF, Goloubeva O, Schayowitz A, Brodie AMH. Stopping treatment can reverse acquired resistance to letrozole. Cancer Res. 2008; 68:4518-4524.

152. Therasse P, Arbuck SG, Eisenhauer EA, et al. New guidelines to evaluate the response to treatment in solid tumors. European Organization for Research and Treatment of Cancer, National Cancer Institute of the United States, National Cancer Institute of Canada. J Natl Cancer Inst. 2000;92:205-216.

153. Therasse P, Eisenhauer EA, Verweij J. RECIST revisited: a review of validation studies on tumour assessment. Eur J Cancer. 2006;42:1031-1039.

154. Gignac GA, Morris MJ, Heller G, Schwartz LH, Scher HI. Assessing outcomes in prostate cancer clinical trials: a twenty-first century tower of Babel. Cancer. 2008;113:966-974.

155. Sahi D, Ohlmann C, Cordia I, Engelmann U, Heidenreich A. A flare-up in patients with hormone-refractory prostate cancer (HRPCA) receiving docetaxel-based chemotherapy: incidence and differentiation from progressive disease. Paper presented at: American Society of Clinical Oncology (ASCO) Annual Meeting; June 2-6, 2006; Atlanta, GA. Abstract 14523.

156. Smith $\mathrm{PH}$, Bono A, Calais da Silva F, et al. Some limitations of the radioisotope bone scan in patients with metastatic prostatic cancer: a subanalysis of EORTC Trial 30853. The EORTC Urological Group. Cancer. 1990;66:1009-1016.

157. Agus DB, Cordon-Cardo C, Fox W, et al. Prostate cancer cell cycle regulators: response to androgen withdrawal and development of androgen independence. J Natl Cancer Inst. 1999;91:1869-1876.

158. Larson SM, Morris M, Gunther I, et al. Tumor localization of $16 \beta-{ }^{18} \mathrm{~F}$-fluoro$5 \alpha$-dihydrotestosterone versus ${ }^{18} \mathrm{~F}$-FDG in patients with progressive, metastatic prostate cancer. J Nucl Med. 2004;45:366-373.

159. Bonasera TA, O’Neil JP, Xu M, et al. Preclinical evaluation of fluorine-18labeled androgen receptor ligands in baboons. J Nucl Med. 1996;37:1009-1015.

160. Choe YS, Lidstrom PJ, Chi DY, Bonasera TA, Welch MJ, Katzenellenbogen JA. Synthesis of 11 beta- $\left[{ }^{18} \mathrm{~F}\right]$ fluoro-5 alpha-dihydrotestosterone and 11 beta$\left[{ }^{18} \mathrm{~F}\right]$ fluoro-19-nor-5 alpha-dihydrotestosterone: preparation via halofluorinationreduction, receptor binding, and tissue distribution. J Med Chem. 1995;38:816-825.

161. Morris MJ, Akhurst T, Larson SM, et al. Fluorodeoxyglucose positron emission tomography as an outcome measure for castrate metastatic prostate cancer treated with antimicrotubule chemotherapy. Clin Cancer Res. 2005;11:3210-3216.

162. Oyama N, Akino H, Suzuki Y, et al. Prognostic value of 2-deoxy-2-[F18]fluoro-D-glucose positron emission tomography imaging for patients with prostate cancer. Mol Imaging Biol. 2002;4:99-104.

163. Shreve PD, Grossman HB, Gross MD, Wahl RL. Metastatic prostate cancer: initial findings of PET with 2-deoxy-2-[F-18]fluoro-D-glucose. Radiology. 1996;199:751-756

164. Schoder H, Herrmann K, Gonen M, et al. 2-[ $\left[{ }^{18} \mathrm{~F}\right]$ fluoro-2-deoxyglucose positron emission tomography for the detection of disease in patients with prostate-specific antigen relapse after radical prostatectomy. Clin Cancer Res. 2005;11:4761-4769.

165. Dehdashti F, Picus J, Michalski JM, et al. Positron tomographic assessment of androgen receptors in prostatic carcinoma. Eur J Nucl Med Mol Imaging. 2005;32:344-350.

166. Utriainen M, Komu M, Vuorinen V, et al. Evaluation of brain tumor metabolism with $\left[{ }^{11} \mathrm{C}\right]$ choline PET and ${ }^{1} \mathrm{H}-\mathrm{MRS}$. J Neurooncol. 2003;62:329-338.

167. Yamamoto Y, Nishiyama Y, Kameyama R, et al. Detection of hepatocellular carcinoma using ${ }^{11} \mathrm{C}$-choline PET: comparison with ${ }^{18} \mathrm{~F}-\mathrm{FDG}$ PET. J Nucl Med. 2008;49:1245-1248.

168. Zhang H, Tian M, Oriuchi N, et al. ${ }^{11} \mathrm{C}$-choline PET for the detection of bone and soft tissue tumours in comparison with FDG PET. Nucl Med Commun. 2003;24:273-279.

169. Hara T, Kosaka N, Kishi H. PET imaging of prostate cancer using carbon-11choline. J Nucl Med. 1998;39:990-995.

170. Kotzerke J, Prang J, Neumaier B, et al. Experience with carbon-11 choline positron emission tomography in prostate carcinoma. Eur J Nucl Med. 2000; 27:1415-1419.

171. de Jong IJ, Pruim J, Elsinga PH, Vaalburg W, Mensink HJ. Visualization of prostate cancer with ${ }^{11} \mathrm{C}$-choline positron emission tomography. Eur Urol. 2002;42:18-23.

172. Eschmann SM, Pfannenberg AC, Rieger A, et al. Comparison of ${ }^{11} \mathrm{C}$-cholinePET/CT and whole body-MRI for staging of prostate cancer. Nuklearmedizin. 2007;46:161-168.

173. Fanti S, Nanni C, Ambrosini V, Gross MD, Rubello D, Farsad M. PET in genitourinary tract cancers. Q J Nucl Med Mol Imaging. 2007;51:260-271.

174. Fazio F, Picchio M, Messa C. Is ${ }^{11} \mathrm{C}$-choline the most appropriate tracer for prostate cancer? Eur J Nucl Med Mol Imaging. 2004;31:753-756.

175. de Jong IJ, Pruim J, Elsinga PH, Vaalburg W, Mensink HJ. Preoperative staging of pelvic lymph nodes in prostate cancer by ${ }^{11} \mathrm{C}$-choline PET. J Nucl Med. 2003;44:331-335.

176. de Jong IJ, Pruim J, Elsinga PH, Vaalburg W, Mensink HJ. ${ }^{11} \mathrm{C}$-choline positron emission tomography for the evaluation after treatment of localized prostate cancer. Eur Urol. 2003;44:32-38.

177. Albrecht S, Buchegger F, Soloviev D, et al. ${ }^{11} \mathrm{C}$-acetate PET in the early evaluation of prostate cancer recurrence. Eur J Nucl Med Mol Imaging. 2007; 34:185-196.

178. Oyama N, Akino H, Kanamaru H, et al. ${ }^{11} \mathrm{C}$-acetate PET imaging of prostate cancer. J Nucl Med. 2002;43:181-186.

179. Oyama N, Miller TR, Dehdashti F, et al. ${ }^{11} \mathrm{C}$-acetate PET imaging of prostate cancer: detection of recurrent disease at PSA relapse. J Nucl Med. 2003; 44:549-555.

180. Sandblom G, Sorensen J, Lundin N, Haggman M, Malmstrom P-U. Positron emission tomography with $\mathrm{C} 11$-acetate for tumor detection and localization in patients with prostate-specific antigen relapse after radical prostatectomy. Urology. 2006;67:996-1000

181. Wachter S, Tomek S, Kurtaran A, et al. ${ }^{11} \mathrm{C}$-acetate positron emission tomography imaging and image fusion with computed tomography and magnetic resonance imaging in patients with recurrent prostate cancer. J Clin Oncol. 2006;24:2513-2519.

182. Kotzerke J, Volkmer BG, Neumaier B, Gschwend JE, Hautmann RE, Reske SN. Carbon-11 acetate positron emission tomography can detect local recurrence of prostate cancer. Eur J Nucl Med Mol Imaging. 2002;29:1380-1384.

183. Fricke E, Machtens S, Hofmann M, et al. Positron emission tomography with ${ }^{11} \mathrm{C}$-acetate and ${ }^{18} \mathrm{~F}$-FDG in prostate cancer patients. Eur J Nucl Med Mol Imaging. 2003;30:607-611.

184. Vavere AL, Kridel SJ, Wheeler FB, Lewis JS. $1{ }^{11} \mathrm{C}$-acetate as a PET radiopharmaceutical for imaging fatty acid synthase expression in prostate cancer. J Nucl Med. 2008;49:327-334.

185. Beer AJ, Haubner R, Wolf I, et al. PET-based human dosimetry of ${ }^{18} \mathrm{~F}$-galacto$\mathrm{RGD}$, a new radiotracer for imaging $\alpha \mathrm{v} \beta 3$ expression. J Nucl Med. 2006; 47:763-769.

186. Beer AJ, Lorenzen S, Metz S, et al. Comparison of integrin $\alpha_{\mathrm{v}} \beta_{3}$ expression and glucose metabolism in primary and metastatic lesions in cancer patients: a PET study using ${ }^{18}$ F-galacto-RGD and ${ }^{18}$ F-FDG. J Nucl Med. 2008;49:22-29.

187. Kenny LM, Coombes RC, Oulie I, et al. Phase I trial of the positron-emitting Arg-Gly-Asp (RGD) peptide radioligand ${ }^{18} \mathrm{~F}$-AH111585 in breast cancer patients. J Nucl Med. 2008;49:879-886.

188. Smith-Jones PM, Solit D, Afroze F, Rosen N, Larson SM. Early tumor response to Hsp90 therapy using HER2 PET: comparison with ${ }^{18} \mathrm{~F}$-FDG PET. J Nucl Med. 2006;47:793-796.

189. Chen W, Cloughesy T, Kamdar N, et al. Imaging proliferation in brain tumors with ${ }^{18}$ F-FLT PET: comparison with ${ }^{18}$ F-FDG. J Nucl Med. 2005; 46:945-952. 